\title{
Status and trends of mercury pollution of the atmosphere and terrestrial ecosystems in Poland
}

\author{
Agnieszka Jędruch, Lucyna Falkowska (1), Dominika Saniewska, \\ Maciej Durkalec, Agnieszka Nawrocka, Elżbieta Kalisińska, \\ Artur Kowalski, Józef M. Pacyna
}

Received: 9 June 2020/Revised: 28 September 2020/Accepted: 15 January 2021/Published online: 23 March 2021

\begin{abstract}
The goal of this paper is to assess the current status and trends of total mercury ( $\mathrm{THg}$ ) contamination of the atmosphere and terrestrial ecosystems in Poland. The study shows that the reduced domestic and worldwide atmospheric emission of $\mathrm{Hg}$ resulted in decreased $\mathrm{THg}$ level in the terrestrial biotope and biosphere. Considering that Poland is one of the main Hg emitters in Europe, the $\mathrm{THg}$ concentrations in its abiotic environment are still elevated. However, the $\mathrm{THg}$ level in terrestrial organisms is relatively low, which is because a large proportion of $\mathrm{Hg}$ deposited on land is accumulated in organic-rich soils. Regarding the THg concentration, consumption of wildlife and livestock from Poland is safe for humans. Nevertheless, the authors indicate the need for effective environmental monitoring, based on selected bioindicators, which is crucial considering the slowing reduction of $\mathrm{Hg}$ emission combined with the consequences of the changing climate.
\end{abstract}

Keywords Animals - Atmosphere - Bioindicators · Mercury $\cdot$ Plants $\cdot$ Temporal trends

\section{INTRODUCTION}

Mercury ( $\mathrm{Hg})$ is a contaminant introduced into the environment from natural sources, including volcanoes and forest fires, re-emission from the ocean and terrestrial surfaces, and anthropogenic activities in the energy production, metallurgy, waste incineration, and other industrial processes. The re-emission of $\mathrm{Hg}$ into the atmosphere

Supplementary Information The online version contains supplementary material available at https://doi.org/10.1007/s13280021-01505-1. plays particularly important role in the $\mathrm{Hg}$ cycle, however, a portion of $\mathrm{Hg}$ circulating currently through the environment media and released years ago, is very difficult to determine (HELCOM 2018; UNEP 2019). It was estimated that, as a result of anthropogenic activity over the past century, the $\mathrm{Hg}$ concentration in the atmosphere has increased by 3 to 5 times and tripled in the surface ocean water (UNEP 2019). Human-caused emission significantly increased the global $\mathrm{Hg}$ pool in the environment and resulted in its elevated concentration in air, water, soil and sediments, often exceeding the geochemical background level (Pacyna et al. 2010; Pirrone et al. 2010; Bishop et al. 2020). For several decades, numerous actions have been taken to reduce the anthropogenic $\mathrm{Hg}$ emission and to prevent its spread in the environment (Pacyna et al. 2010; EMEP 2016). The Minamata Convention (UNEP 2013), creating a legal framework to protect human health and the environment from the adverse effects of $\mathrm{Hg}$, sets out the direction of necessary actions for efficient control of the environment and its protection for future generations. The European Union (EU) Member States have committed themselves to conduct long-term policy and international cooperation to reduce $\mathrm{Hg}$ emissions and subsequent deposition in the environment (UNEP 2013, 2019; EC 2017). The Minamata Convention is a significant challenge for Poland, a country with some of the highest Hg emissions and depositions in Europe (in 2016 Poland accounted for $18 \%$ of total atmospheric $\mathrm{Hg}$ emission in the EU) (EEA 2018). Nevertheless, Poland took actions leading to a substantial reduction in $\mathrm{Hg}$ emission at the end of the twentieth century thereby contributing to a decrease in the Hg deposition (Pacyna et al. 2010; Zhang et al. 2016; HELCOM 2018; KOBiZE 2019).

The current model-based estimates of $\mathrm{Hg}$ inflow (EMEP 2016, 2018; HELCOM 2018) suggest that the biotope and 
biosphere in Central Europe may be more exposed to $\mathrm{Hg}$ than other regions. This is related to the industrialisation of this area, especially the carbon-based energy economy of its countries, which is a major source of $\mathrm{Hg}$. Therefore, a primary goal of this paper is to investigate the exposure to $\mathrm{Hg}$ of terrestrial flora and fauna from Poland. We also aim to determine not only the current status of total $\mathrm{Hg}$ ( $\mathrm{THg}$ ) in biota but also to indicate time trends of $\mathrm{THg}$ level and factors conditioning them. We hypothesise that the decrease of $\mathrm{THg}$ concentration in the terrestrial food webs results from a reduction in anthropogenic emission and thus deposition of $\mathrm{Hg}$. However, ongoing climate change and other environmental pressures may affect this tendency. Consequently, the pool of bioavailable $\mathrm{Hg}$ and its tropic transfer may both increase.

\section{MATERIALS AND METHODS}

In Poland, the first results on $\mathrm{Hg}$ level, both in the case of terrestrial (i.e. Szprengier 1976; Kossakowski 1979) and freshwater ecosystems (i.e. Nabrzyski 1975; Gajewska and Nabrzyski 1977), date back to the 1970s. Although methylmercury (MeHg) is one of the most poisonous among $\mathrm{Hg}$ compounds, this study focuses only on $\mathrm{THg}$. This is because the knowledge of $\mathrm{Hg}$ speciation, both in abiotic and biotic environmental compartments in Poland, is mostly based on very limited data. To determine the status and the temporal trends of $\mathrm{THg}$ pollution in Poland, a total of 85 data sources were used in this work, while the discussion of the results was based on additional 163 literature sources (Fig. S1). Due to the arrangement of the article, some of these references are provided in Electronic Supplementary Material (ESM). Besides information on data collection, the ESM also contains details of results analysis.

\section{DISCUSSION}

\section{Hg level in abiotic environmental compartments}

The land surface contributes to a complex bi-directional $\mathrm{Hg}$ exchange with the atmosphere. $\mathrm{Hg}$ deposited on land enters the soil that constitutes the largest pool of $\mathrm{Hg}$ in the terrestrial environment. Surface runoff and soil erosion are a major source of $\mathrm{Hg}$ that accumulates in biota from aquatic ecosystems (Kowalski et al. 2007; Jędruch et al. 2019; Bishop et al. 2020). In this part, we summarise the findings on $\mathrm{THg}$ level in the key abiotic components of the terrestrial environment, namely atmosphere (Sect. Atmosphere), soil (Sect. Soil), and freshwater bodies (Sect. Waterbodies), conducted in Poland.

\section{Atmosphere}

The main sources of anthropogenic $\mathrm{Hg}$ are processes involving high temperatures, including the burning of fossil fuels, the smelting of non-ferrous metals, iron and steel foundries, as well as the cement industry and gold production. In Poland, $71 \%$ of $\mathrm{Hg}$ is emitted from the energy sector, while the industrial processes and product use are responsible for $26 \%$ of total national $\mathrm{Hg}$ emission (KOBiZE 2019). However, it is estimated that only about half of the atmospheric $\mathrm{Hg}$ in Poland originates from its territory. The remaining $\mathrm{Hg}$ pool is transported mainly from Western European countries along with air masses travelling from the south-west of the continent (Petersen 1999). The most important $\mathrm{Hg}$ sources to the atmosphere in Poland are located in industrial regions. In Silesia region (southern Poland), which is one of the European air pollution 'hot-spots', the $\mathrm{Hg}$ emission was $3.5 \mathrm{Mg}$ in 2005, while in the less industrialised regions (western and northern Poland) it amounted to $0.2 \mathrm{Mg}$ (Hławiczka 2008). Due to the use of coal as the primary energy source in Poland, individual home furnaces are seen as the major cause of local or dispersed air pollution.

$\mathrm{Hg}$ is emitted into the atmosphere mainly in gaseous elemental form and can remain there for 12-18 months (Holmes et al. 2006). In 2017, the average concentration of total gaseous mercury (TGM) measured at non-urban stations $\left(1.5 \mathrm{ng} \mathrm{m}^{-3}\right)$ was $25 \%$ higher than the European average TGM concentration $\left(1.2 \mathrm{ng} \mathrm{m}^{-3}\right.$ ) (Skotak et al. 2019). TGM values measured in Poland were similar to those observed in other industrialised countries, such as Germany $\left(1.5 \mathrm{ng} \mathrm{m}^{-3}\right)$ and $\mathrm{UK}\left(1.4 \mathrm{ng} \mathrm{m}^{-3}\right)$. The high average TGM level in Poland was affected by the results obtained at the stations located in the polluted southern part of the country, where the annual TGM concentrations were $1.7 \mathrm{ng} \mathrm{m}^{-3}$ or higher (Skotak et al. 2019). A similar trend was also observed for the total particulate mercury (TPM). In northern Poland, the TPM concentrations (Korejwo et al. 2020) were similar to those measured in the Swedish coastal zone (around $10 \mathrm{pg} \mathrm{m}^{-3}$ ) (Wängberg et al. 2001), while in southern Poland $\mathrm{Hg}$ concentration in the particulate matter oscillated around $30 \mathrm{pg} \mathrm{m}^{-3}$ (Pyta et al. 2020). TGM can be oxidised to $\mathrm{Hg}^{2+}$, which is much more reactive, hence it is removed from the atmosphere with dry and wet deposition. A dry deposition usually accounts for less than $30 \%$ of the total atmospheric $\mathrm{Hg}$ inflow, which was noted in Poland (Saniewska et al. 2014a; Bełdowska et al. 2016), as well as in other regions of the Baltic area (www.ebas.nilu.no). The $\mathrm{Hg}$ deposition in Poland fluctuates spatially. In northern Poland it varies from 10 to $15 \mathrm{~g} \mathrm{~km}^{-2}$ year $^{-1}$ and is similar to the $\mathrm{Hg}$ deposition flux over the southern Baltic Sea. In central Poland, atmospheric deposition of $\mathrm{Hg}$ ranges from 15 to 
$30 \mathrm{~g} \mathrm{~km}^{-2}$ year $^{-1}$, while the industrialised south of the country receives over $30 \mathrm{~g} \mathrm{~km}^{-2}$ year ${ }^{-1}$ (EMEP, 2016).

In 1983-1989 the estimated emission of $\mathrm{Hg}$ from Polish territory exceeded $20 \mathrm{Mg}_{\text {year }}{ }^{-1}$ and increased on average by $0.27 \mathrm{Mg}$ year $^{-1}$ (Pirrone et al. 1996). The reduction of $\mathrm{Hg}$ emission in Poland took place in 1990-2002 and amounted to $-0.43 \mathrm{Mg} \mathrm{year}^{-1}$. The stabilisation period for $\mathrm{Hg}$ emissions occurred in the years 2003-2017 with a weak trend of $-0.1 \mathrm{Mg}$ year $^{-1}$. The latest data show that the national emission of $\mathrm{Hg}$ does not exceed $10 \mathrm{Mg}$ year $^{-1}$ (Fig. S2). However, it should be noted that the decrease in $\mathrm{Hg}$ emission in Poland (by $42 \%$ since 1990) is one of the smallest among European countries reported to the Convention on Long-range Transboundary Air Pollution (LRTAP). To compare, during this period, $\mathrm{Hg}$ emissions in Germany and Sweden were reduced by $74 \%$ and in the UK by $90 \%$ (EEA 2019). Along with long-term changes in $\mathrm{Hg}$ emissions from the territory of Poland, there were simultaneous changes in its deposition (Fig. 1). The strongest decreasing trend by $30-40 \%$ in $\mathrm{Hg}$ concentration in the air noted in the northern hemisphere in the 1990s resulted from the intentional withdrawal of $\mathrm{Hg}$ from commercial products and control technologies. For the 1990-2012 period, Zhang et al. (2016) determined a decrease in $\mathrm{Hg}^{0}$ concentration in the atmosphere and its deposition at $-2.1 \%$ year $^{-1}$ and $-2.2 \%$ year $^{-1}$, respectively. There is no doubt that $\mathrm{Hg}$ emission forecasts indicate its slow reduction, but global emission models are not as optimistic, depending on the adopted scenario (Rafaj et al. 2013; UNEP 2013). According to emission control strategy, the decrease in $\mathrm{Hg}$ concentration in remote industrial areas may amount to $15-20 \%$ of the present level. Maintaining the emission status quo in industrialised regions can contribute to an increase in $\mathrm{Hg}$ levels of 2 to $25 \%$, and 1.5 to $5 \%$ away from these regions. Even a small increase in anthropogenic emissions or re-emission from $\mathrm{Hg}$ accumulation areas may cause significant emission growth.

\section{Soil}

$\mathrm{Hg}$ concentration in soil is related to its geological structure and human activity in a given area. The average $\mathrm{THg}$ content in Polish soils usually did not exceed $50 \mathrm{ng} \mathrm{g}^{-1} \mathrm{dw}$ (dry weight), which is considered as the geochemical background (Pasieczna 2012). The average THg concentration in soils from non-built-up areas was $17 \mathrm{ng} \mathrm{g}^{-1} \mathrm{dw}$ which is close to the mean concentration in unpolluted European soils. In southern Poland, higher THg concentration in soil (over $60 \mathrm{ng} \mathrm{g}^{-1} \mathrm{dw}$ ) was associated with the elevated $\mathrm{Hg}$ level in the bedrock (FOREGS 2005) (Fig. 2). In general, the $\mathrm{THg}$ content in urban soils was 2 to 4 times higher than in background areas (Pasieczna 2012). Research conducted in northern Poland has shown that over $70 \%$ of $\mathrm{THg}$ in soil occurred in the soluble labile fraction (i.e. $\mathrm{Hg}$ halides, $\mathrm{Hg}$ bound to humic acids or $\mathrm{MeHg}$ ), while stable and insoluble forms (i.e. $\mathrm{HgS}$ or matrix-bound $\mathrm{Hg}$ ) accounted for less than 30\% (Gębka et al. 2020). Similar results were obtained in contaminated soil from southern Poland, where about $35 \%$ of soil $\mathrm{Hg}$ was in stable form (Pogrzeba et al. 2016). During the twentieth and twenty-

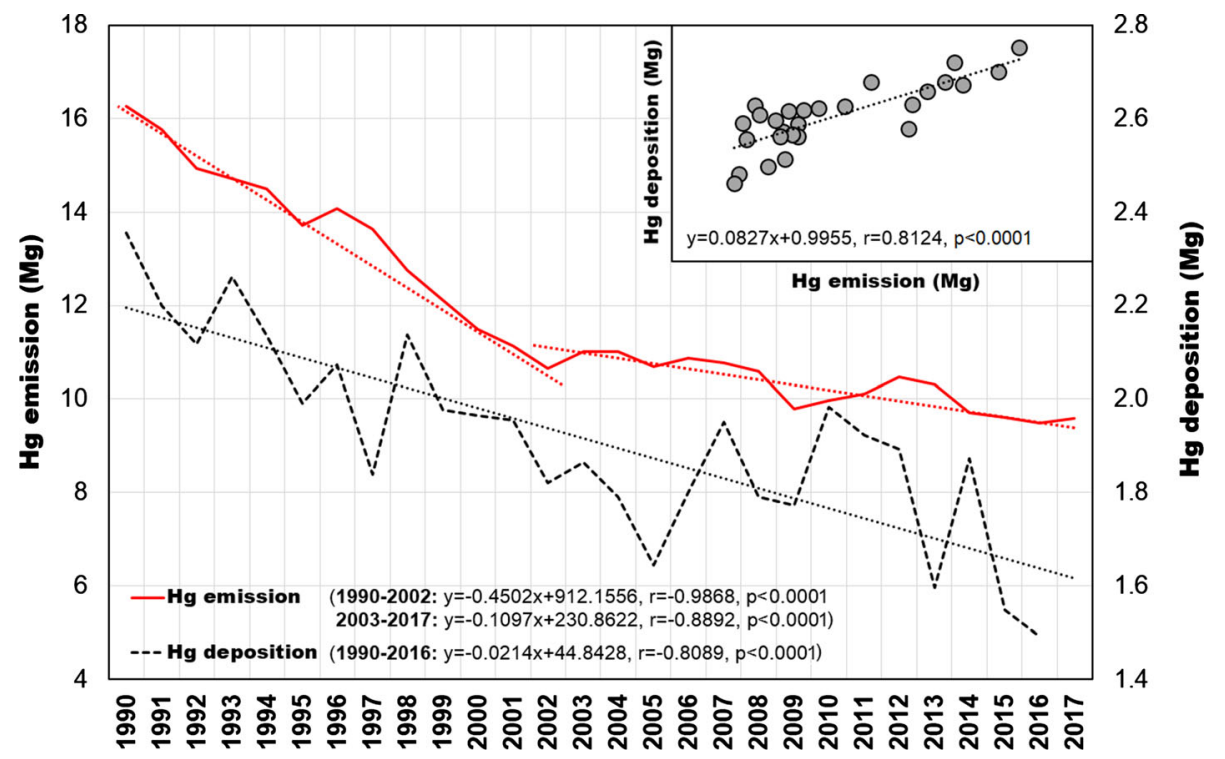

Fig. 1 Long-term changes in annual total $\mathrm{Hg}$ emission (Mg) and deposition (Mg) in Poland and southern Baltic Sea (EMEP 2018; KOBiZE, 2019) 


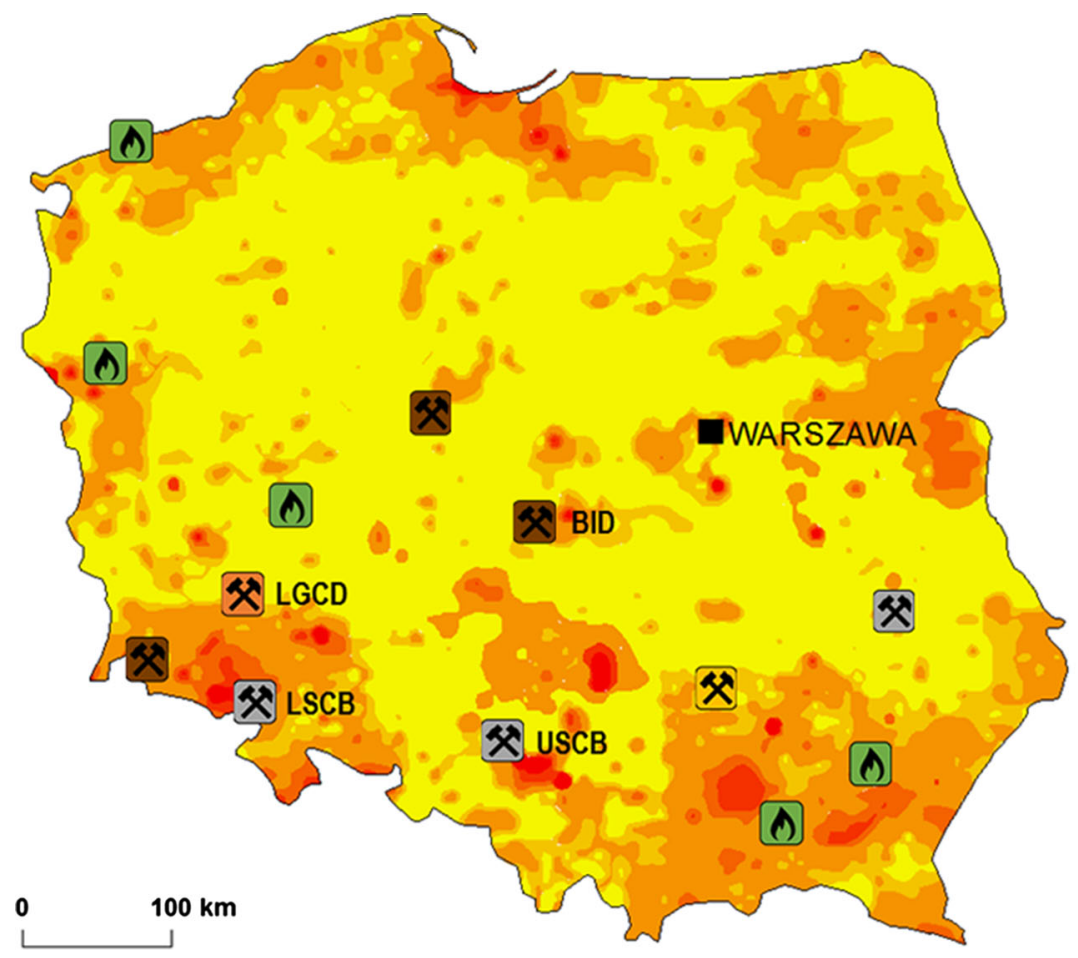

THg in topsoil (ng g-1 $\mathrm{dw}^{-1}$

\begin{tabular}{|l}
$\square<50$ (natural background) \\
$51-60$ \\
$61-100$ \\
$101-140$ \\
$141-180$ \\
$>180$ \\
\hline$\square$
\end{tabular}

\section{Mineral resources}

X Hard coal

Lignite

(A) Natural gas and crude oil

(X) Copper ore

Sulfur ore

USCB Upper Silesian Coal Basin LSCB Lower Silesian Coal Basin

BID Betchatów Industrial District

LGCD Legnica-Głogów Copper District

Fig. 2 Total $\mathrm{Hg}(\mathrm{THg})$ concentration $\left(\mathrm{ng} \mathrm{g}^{-1} \mathrm{dw}\right)$ in the topsoil $(0-20 \mathrm{~cm})$ in Poland (based on data published by Pasieczna (2012)) in 1991-1992 together with the locations of main mineral resources and industrial districts

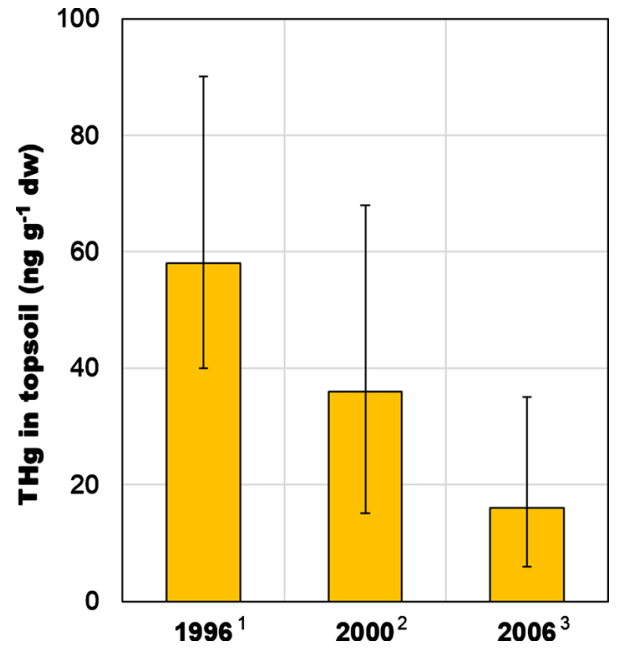

Fig. 3 Total $\mathrm{Hg}(\mathrm{THg})$ concentration $\left(\mathrm{ng} \mathrm{g}^{-1} \mathrm{dw}\right)$ (mean and range) in the topsoil of northern Poland (Tri-City Landscape Park) $\left({ }^{1}\right.$ Falandysz et al. 2003; ${ }^{2}$ Falandysz and Bielawski 2007; ${ }^{3}$ Saba et al. 2016)

first century THg concentration in soils of the industrialised and urbanised areas of northern Poland decreased threefold (Fig. 3), which was probably a response to the reduction of $\mathrm{Hg}$ emissions and deposition that took place in Poland in the 1990s (Fig. 1).
The outflow of $\mathrm{Hg}$ from soils into rivers depends on the retention capacity of the catchment area. In natural regions, only $10-30 \%$ of $\mathrm{Hg}$ deposited from the atmosphere flows from the catchment area to the river, while in the humantransformed catchment the $\mathrm{Hg}$ outflow can reach 65\% (Driscoll et al. 1998). Research by Saniewska et al. (2014b, 2019) showed that in transformed areas, water in rivers was several times more contaminated with $\mathrm{THg}$ compared to natural areas. This is important as the agricultural areas cover two-thirds of Poland, which stimulates such a great $\mathrm{Hg}$ outflow from soil to rivers and then to the sea. As shown by Driscoll et al. (1998) over 70\% of $\mathrm{Hg}$ deposited on land retains in the soil and due to atmospheric deposition, this pool is successively supplemented. This means that soil is not only storage but also an important $\mathrm{Hg}$ source to the aquatic environment and will remain so for several thousands of years (Larssen et al. 2008).

\section{Waterbodies}

$\mathrm{Hg}$ enters the freshwater ecosystem mainly through outflow from soils. The Hg level in water is affected mainly by the concentration of dissolved organic matter, which is a link between land and the aquatic environment. It is also influenced by physicochemical parameters, land cover or watershed disturbances (Bravo et al. 2018; Bishop et al. 2020). In comparison to soils, the level of $\mathrm{Hg}$ in the water 
of rivers and lakes in Poland is understudied, which is mainly due to the methodological difficulties of $\mathrm{Hg}$ analysis in liquid samples versus solid matrices. Although the $\mathrm{THg}$ concentration in rivers is routinely monitored, owing the weaknesses of the analytical methods used, such as limits of quantification often exceeding the $\mathrm{THg}$ level in the water (HELCOM 2018), the number of reliable data are low. The $\mathrm{THg}$ concentration in the unfiltered water of Vistula, the largest river in Poland and the second largest river discharging into the Baltic Sea, averaged to $6.3 \mathrm{ng}$ $\mathrm{L}^{-1}$ and the ranged from 4.7 to $11.7 \mathrm{ng} \mathrm{L}^{-1}$ during the year (Saniewska et al. 2014c) (Table S1a). These concentrations met the EU environmental quality standards (EQS) for $\mathrm{THg}$ concentration in inland waters (EC 2008), moreover none of the values exceeded $12 \mathrm{ng} \mathrm{L}^{-1}$, above which the chronic toxic effects on aquatic organisms is observed (US EPA 1992). In small watercourses in northern Poland, the $\mathrm{THg}$ concentration was similar to the Vistula and ranged from 4.1 to $6.7 \mathrm{ng} \mathrm{L}^{-1}$ (Gębka et al. 2018). The highest $\mathrm{THg}$ concentration in rivers occurred during thaws, which released pollutants that had been accumulating over the winter (Gębka et al. 2020). Downpours and floods had a crucial impact on a $\mathrm{THg}$ load carried by rivers (Saniewska et al. 2014c; Jędruch et al. 2017) (Table S1b). During these periods, the daily outflow of $\mathrm{THg}$ from soil was estimated at $90-150 \%$ of the daily wet deposition flux (Saniewska et al. 2018).

The results of a large-scale study conducted in streams across Europe by Bravo et al. (2018), showed that the measured THg concentrations were lower than in Polish rivers, and ranged from 0.1 to $2.8 \mathrm{ng} \mathrm{L}^{-1}$ (Table S1a). These differences result mainly from the type of catchment area, i.e. streams enriched in terrestrial dissolved organic matter revealed the elevated total $\mathrm{Hg}$ concentrations, as in the case of Sweden or UK (Bravo et al. 2018). This may therefore indicate that one of the factors influencing higher $\mathrm{THg}$ concentrations in Polish rivers is the agriculturedominated catchment. Moreover, the $\mathrm{THg}$ concentrations in Poland were similar to values measured in the agricultural watercourses in Sweden (2.4-4.5 ng L ${ }^{-1}$ ) (Eklöf et al. 2012). Unfortunately, there are no data on the $\mathrm{MeHg}$ concentration in the riverine water in Poland. Considering the share of $\mathrm{MeHg}$ in $\mathrm{THg}$ in the European rivers varied widely from 1 to $43 \%$ (Bravo et al. 2018), it is hard to estimate its percentage in Polish watercourses.

The THg concentration in waters of lakes and ponds in western Poland was several times higher compared to rivers and ranged from 8 to $24 \mathrm{ng} \mathrm{L}^{-1}$ and 16 to $31 \mathrm{ng} \mathrm{L}^{-1}$, respectively (Kowalski et al. 2007). In lakes considered as polluted, $\mathrm{Hg}$ concentration in the water exceeded $100 \mathrm{ng}$ $\mathrm{L}^{-1}$ (Baralkiewicz et al. 2006). This may be of environmental importance considering that the share of toxic $\mathrm{MeHg}$ in water was relatively high and amounted to about
$10 \%$ of $\mathrm{THg}$, which is consistent with the results of studies carried out in boreal and subarctic lakes (Emmerton et al. 2018). The results indicate that Polish lakes are more contaminated with $\mathrm{THg}$ than lakes from southern Scandinavia (Lindström 2001; Braaten et al. 2014). However, the available data are very local and do not reflect the scale of the $\mathrm{THg}$ pollution of lakes in Poland.

\section{Hg level in terrestrial plants and animals}

Most studies on $\mathrm{Hg}$ level in organisms have focused on the aquatic environment, and the role of $\mathrm{Hg}$ accumulation in terrestrial food webs is neglected. A clear preponderance of research from aquatic and marine environments compared to terrestrial ecosystems, where relatively few evaluations exist, was highlighted by many scientists (Gnamuš et al. 2000; Bishop et al. 2020).

The knowledge of the $\mathrm{Hg}$ cycle and trophic transfer in terrestrial ecosystems in Poland, like in other regions of the world, is quite limited. Here, the focus is on $\mathrm{THg}$ accumulation in the terrestrial organisms from different trophic levels, especially those essential for the human diet. The selected elements include plants and macrofungi (Sect. Plants and fungi); freshwater fish (Sect. Freshwater fish); wild animals, including primary and secondary consumers (Sect. Wild animals); and livestock (Sect. Livestock) as the main source of animal protein for humans.

\section{Plants and fungi}

Terrestrial vegetation absorbs $\mathrm{Hg}$ primarily from the atmosphere via their stomata while the $\mathrm{Hg}$ uptake from the soil via roots is less significant (Stamenkovic and Gustin 2009). Terrestrial plants have been used as bioindicators of environmental $\mathrm{Hg}$ pollution for years. Mosses and lichens are particularly sensitive indicators, useful for determining the atmospheric deposition of Hg (Bargagli 2016; www.ivl. se), however, tree leaves are also commonly used for this purpose (De Nicola et al. 2013).

In wild-growing plants of Poland, the THg concentration was relatively low, which is confirmed, among others, by the studies on $\mathrm{Hg}$ in mosses. In unpolluted areas, both in the north and the south of Poland, the THg concentration in these plants ranged from 11 to $35 \mathrm{ng} \mathrm{g}^{-1} \mathrm{dw}$ (Table S2a). These values were among the lowest values measured in mosses collected throughout Europe. Increased THg concentration was observed only in the mountains located in southeastern Poland, which is associated not only with the proximity of anthropogenic $\mathrm{Hg}$ sources (Fig. 2) but also with the increased natural $\mathrm{Hg}$ content in the bedrock (Pasieczna 2012). Higher THg concentrations were measured in the leaves of trees-Norway maple (Acer plantanoides) and large-leaved linden (Tilia platyphyllos), in 
which they ranged from 12 to $107 \mathrm{ng} \mathrm{g}^{-1} \mathrm{dw}$, amounting to $48 \mathrm{ng} \mathrm{g}^{-1} \mathrm{dw}$ on average (Kowalski and Frankowski 2016). This is associated not only with the atmospheric $\mathrm{Hg}$ deposition but also with the transport of $\mathrm{Hg}$ to leaves via conductive tissues od trees. In the terrestrial plants, including grasses, herbs or tree leaves, the majority of $\mathrm{Hg}$ is present as a $\mathrm{Hg}(\mathrm{II})$, a slight proportion of $\mathrm{MeHg}$ is also detected in some cases. According to research conducted in the Czech Republic (Mališová et al. 2015) and Germany (Schwesig and Krebs 2003), the $\mathrm{MeHg}$ percentage in $\mathrm{THg}$ in the aboveground parts was lower (up to $0.5 \%$ ) than in roots (up to $6 \%$ ), which may be a result of the microbial methylation of $\mathrm{Hg}$ in the root-soil interface. Given the substantial biomass of trees, the litterfall from the deciduous plants at the end of the growing season to soils and the surface waters can be a significant source of $\mathrm{Hg}$ input to those systems. This load may increase due to longer exposure of leaves to atmospheric $\mathrm{Hg}$ during the year as the vegetation season in Poland becomes longer.

Macrofungi are important food for animals, including insects, snails, rodents, deer and wild boars and the fungal spores can account for up to $35 \%$ of their stomach volume (Nawrocka et al. 2020). Wild-growing mushrooms are also a popular component of the human diet, especially in Poland, which is also the second-largest producer of mushrooms in Europe. Among the popular edible species, the lowest mean $\mathrm{THg}$ concentration of $35 \mathrm{ng} \mathrm{g}^{-1} \mathrm{dw}$ was measured in the common chanterelle (Cantharellus spp.) (Fig. 4a). In the caps of the brown birch bolete (Leccinum scabrum), it was twice as high and averaged $570 \mathrm{ng} \mathrm{g}^{-1} \mathrm{dw}$ (Fig. 4b). The highest $\mathrm{THg}$ level, among investigated mushroom species, was measured in the king bolete (Boletus edulis) (Fig. 4c), in which the mean concentration was $3000 \mathrm{ng} \mathrm{g}^{-1} \mathrm{dw}$, and in the parasol mushroom (Macrolepiota procera) with the mean $\mathrm{THg}$ concentration of 3 $800 \mathrm{ng} \mathrm{g}^{-1} \mathrm{dw}$ (Falandysz et al. 2007; Mazurkiewicz and Podlasińska 2014). These values are much higher than the safe level of THg for edible mushrooms, set by the Polish Ministry of Health, which amounts to $500 \mathrm{ng} \mathrm{g}^{-1} \mathrm{dw}$. The maximum $\mathrm{THg}$ concentrations measured in the caps of these fungi were more than double the mean value, which if consumed excessively, can lead to adverse health effects
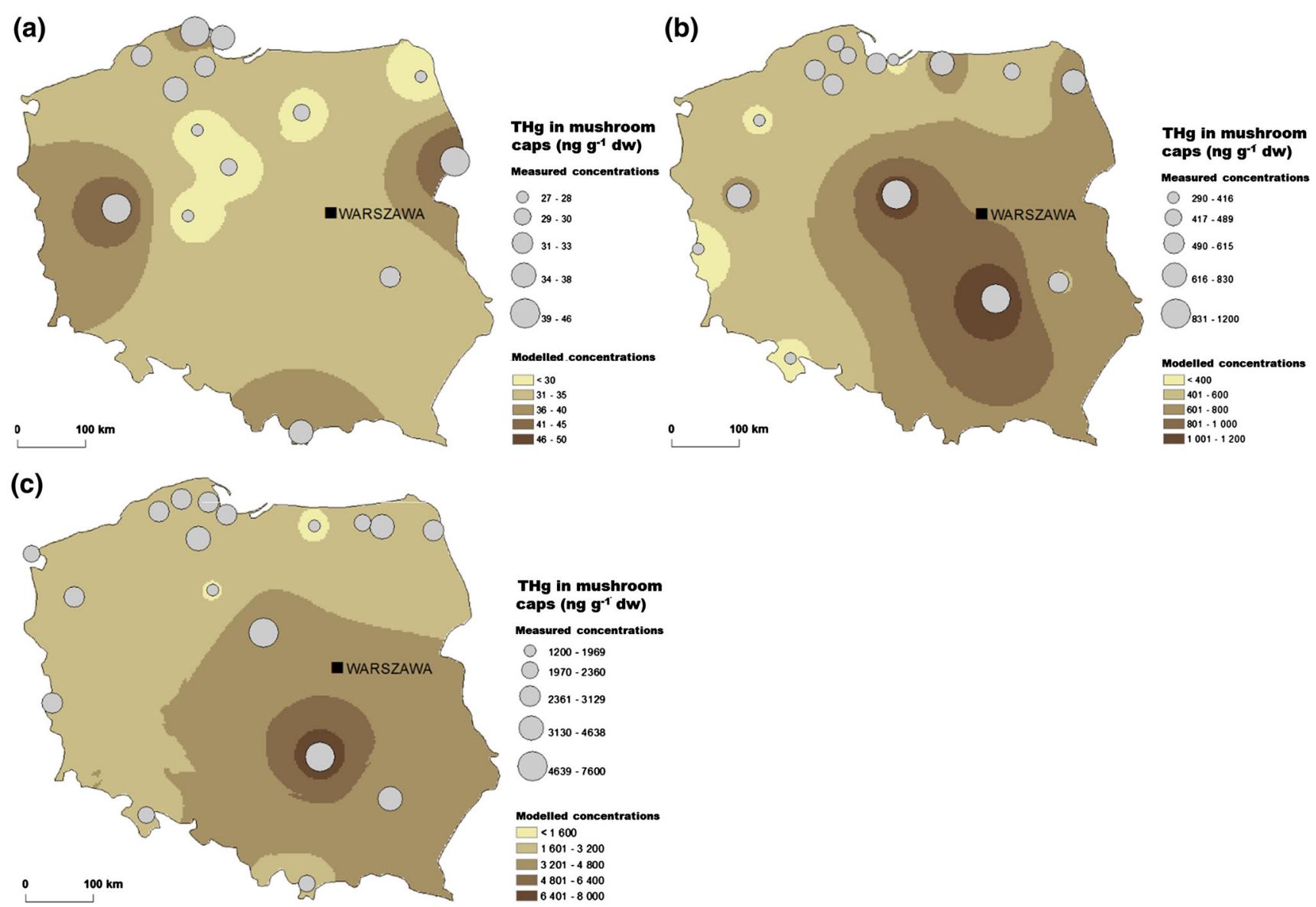

Fig. 4 Total $\mathrm{Hg}(\mathrm{THg})$ concentration $\left(\mathrm{ng} \mathrm{g}^{-1} \mathrm{dw}\right.$ ) in caps of edible mushrooms from Poland in years 1994-2009: a common chanterelle, b brown birch bolete, and c king bolete (Falandysz and Chwir 1997; Falandysz and Bielawski 2007; Falandysz et al. 2003, 2007, 2012; Mazurkiewicz and Podlasińska 2014) 
(Table S2c). Moreover, as shown by the study carried out in Switzerland, the contribution of $\mathrm{MeHg}$ in fruiting bodies of mushrooms can reach up to $11 \%$ of $\mathrm{THg}$ (Rieder et al. 2011). Given that the mushroom season in Europe is getting longer in recent decades, macrofungi can constitute available $\mathrm{Hg}$ source for animals throughout the whole year.

Numerous studies (Falandysz and Chwir 1997; Falandysz et al. 2007; Musilová et al. 2019) showed that mushrooms could act as bioindicators of $\mathrm{Hg}$ pollution. However, the process of $\mathrm{Hg}$ uptake by mushrooms is species-specific, and some taxa contain an elevated concentration of $\mathrm{THg}$ due to preferential bio-uptake from the soil. Based on the available literature data, it can be concluded that the brown birch bolete (Leccinum scabrum) can be used as an indicator species. The reason for this is the positive relationship between the $\mathrm{THg}$ concentration in the fungus tissue and the underlying substrate, especially in contaminated areas. In the case of this species, the increased levels of $\mathrm{THg}$ in caps correspond quite well to the increased $\mathrm{THg}$ level in soils and the location of point sources of $\mathrm{Hg}$ (Figs. 2, 4b).

\section{Freshwater fish}

Research on freshwater fish in Poland showed that the trophic preferences of a given species had a great influence on THg concentration levels in fish muscles (Fig. 5a). Low $\mathrm{THg}$ concentration in planktivorous fish and high ones in predatory fish indicate the transfer of $\mathrm{Hg}$ in the aquatic food chain, a process which is emphasised by many authors who also point to the importance of species-specific characteristics (Lavoie et al. 2013; Wang et al. 2019). The highest $\mathrm{THg}$ level among predatory species was measured in muscles of pike (229 $\mathrm{ng} \mathrm{g}^{-1} \mathrm{ww}$ (wet weight)). It was similar in the case of Scandinavian lakes, although $\mathrm{THg}$ concentration in this species was 4 times higher than in Poland. In the case of other predatory species, the perch (Perca fluviatilis), THg concentration measured in Sweden and Finland was over twice as high as in Poland (Miller et al. 2013; Braaten et al. 2019). The possible explanation for the high $\mathrm{THg}$ concentration in fish from Scandinavia is elevated concentration of $\mathrm{Hg}$ in the underlying bedrock, as its geology strongly influences the $\mathrm{Hg}$ level in the water and hence in aquatic fauna (Danielsson et al. 2011; www. sgu.se). Elevated THg level in freshwater biota in Scandinavia may also by the result of forestry and other alterations of the landscape that promote the mobilisation of $\mathrm{THg}$ and $\mathrm{MeHg}$ and their transport from soils to surface waters and consequently greater bioaccumulation and biomagnification (Bishop et al. 2009; www.svo.se). THg concentration in predatory fish was close to the level found in benthivorous fish, such as the tench (Tinca tinca), the crucian carp (Carassius carassius) or the burbot (Lota lota)
(Fig. 5a). Wyrzykowska et al. (2012) showed that in some species of benthic fish the $\mathrm{THg}$ level in muscles was similar to predatory fish and exceed the EU acceptable maximum levels of $\mathrm{Hg}$ in fish $\left(500 \mathrm{ng} \mathrm{g}^{-1} \mathrm{ww}\right)$. However, the mean $\mathrm{THg}$ concentration in the muscles of near-bottom freshwater fish in Poland was over 100 times lower than the concentration in fish of the Czech Republic and over 4 times greater than in Germany (Table S3a). Planktivorous fish caught in Poland, the common rudd (Scardinius erythrophthalmus) and the vendace (Coregonus albula), most often had a THg concentration in muscles below $100 \mathrm{ng} \mathrm{g}^{-1}$ ww (Fig. 5a). The results of the several years' research indicate that the $\mathrm{THg}$ concentration in freshwater fish from Poland, in most cases were well below the permissible limit set out by the EU. According to the Water Framework Directive, the EQS concerning $\mathrm{THg}$ in fish should not exceed $20 \mathrm{ng} \mathrm{g}^{-1}$ ww. Unfortunately, in Poland, as in many other EU countries, the EQS for $\mathrm{Hg}$ are far from 'good status' (EEA 2018). Considering the risk to human health caused by freshwater fish consumption, but also the exposure of piscivorous animals, it is important to note that the majority of $\mathrm{THg}$ in fish tissues is $\mathrm{MeHg}$. As shown by the studies conducted in the freshwater and brackish ecosystems of northern Poland, the percentage of $\mathrm{MeHg}$ in the muscle tissue of fish (i.e. perch, pike-perch, common roach, common bream) averaged 70-80\% (Polak-Juszczak and Nermer 2016; Polak-Juszczak 2017). For comparison, in the muscles of fish collected from the polluted reservoir in the Czech Republic, almost $100 \%$ of $\mathrm{THg}$ was $\mathrm{MeHg}$ (Maršálek et al. 2005), which may be related to the usually occurring positive correlation between the $\mathrm{THg}$ concentration and the contribution of $\mathrm{MeHg}$ in the tissues and organs of fish. In the fish liver, the proportion of $\mathrm{MeHg}$ varied in a wide range from less than 30 to over $80 \%$, which was connected to the efficiency of the demethylation in this organ (Polak-Juszczak 2017).

\section{Wild animals}

The available results for $\mathrm{THg}$ concentration in the tissues of wild terrestrial mammals representing different taxonomic units indicate a dependence on the trophic level. The lowest $\mathrm{THg}$ concentration (about $1 \mathrm{ng} \mathrm{g}^{-1} \mathrm{ww}$ ) was found in the muscle tissue of herbivores, including the European rabbit (Oryctolagus cuniculus), the roe deer (Capreolus capreolus) and the red deer (Cervus elaphus). Higher levels occurred in the muscle tissue of the European hare (Lepus europaeus) and the Eurasian beaver (Castor fiber) (Fig. 5b), which is probably because hares and beavers prefer foods with a higher $\mathrm{Hg}$ concentration-plants and crops rich in fat in the case of hares, and water macrophytes and tree bark in the case of beavers. Among omnivorous animals, elevated $\mathrm{THg}$ concentration was 
(a)

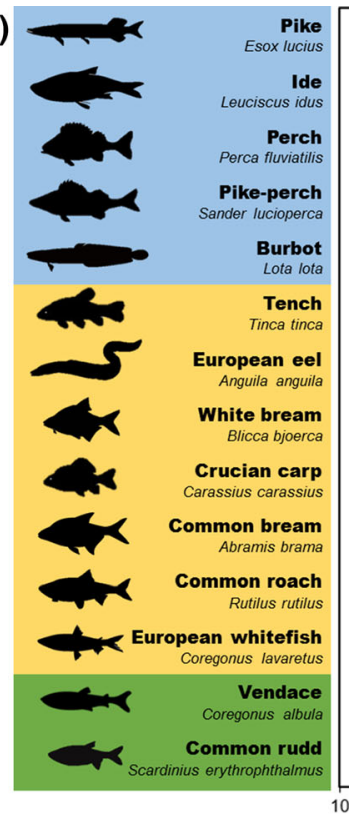

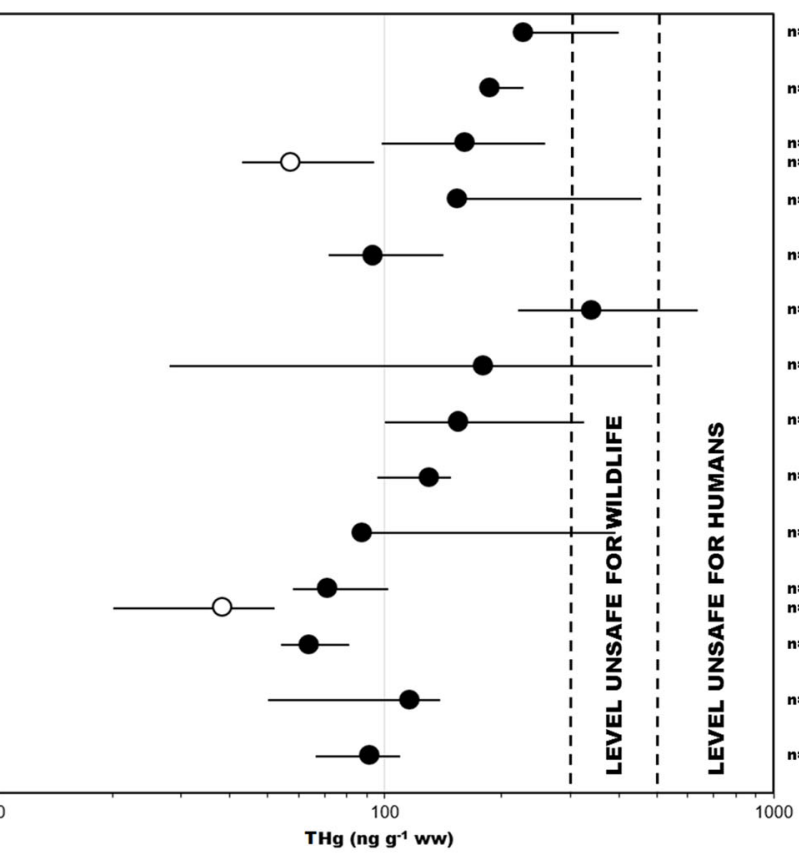

$n=58$ $n=3$ $n=10$ $n=63$ $=3$ $n=7$ $n=64$ $n=5$

=100 Tissue

- Muscle

n=10 -O- Liver

Trophic group

$\square$ Piscivorous

Benthivorous

Planktivorous

(b)

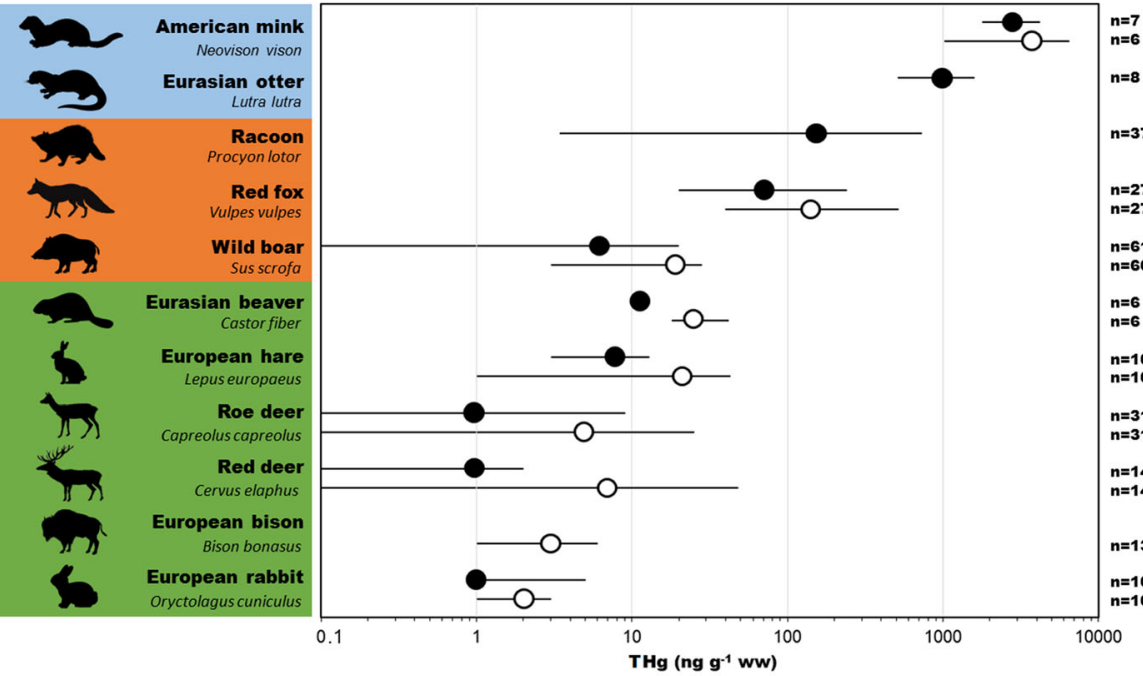

(c)

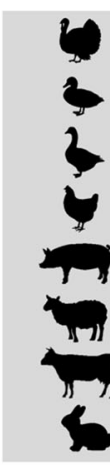

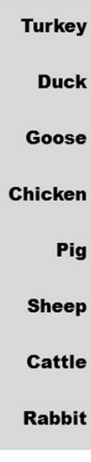

\begin{tabular}{c} 
Turkey \\
Duck \\
Goose \\
Chicken \\
Pig \\
Sheep \\
Cattle \\
\hline Rabbit
\end{tabular}

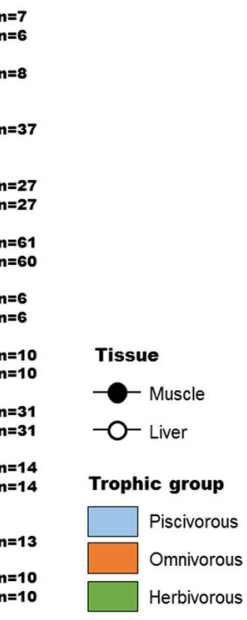

THg (ng g-1 ww)

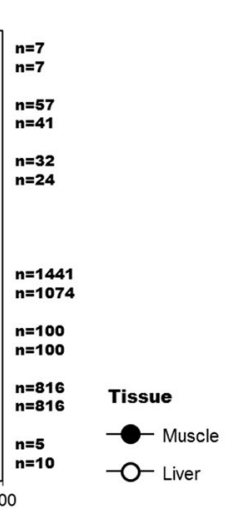

Fig. 5 Total $\mathrm{Hg}(\mathrm{THg})$ concentration (ng g ${ }^{-1} \mathrm{ww}$ ) (mean and range) in muscles and livers of terrestrial animals with different feeding habits: a freshwater fish, $\mathbf{b}$ wild animals, and $\mathbf{c}$ livestock from Poland (values and references are given in the Table S4) 
found in the muscle tissue of species for which predation is more dominant compared to more herbivorous species, such as the wild boar (Sus scrofa), the racoon (Procyon lotor) and the red fox (Vulpes vulpes) (Fig. 5b). Boars are highly versatile omnivores and the majority of their diet consists of food items dug from the ground, like plant material and burrowing animals. As omnivorous opportunistic feeders, raccoons feed on whatever is easiest to find, including carrion, rodents, molluscs and crustaceans, fish, injured waterfowl and their eggs and nestling. The diet of the red fox consists mainly of rodents, birds or ungulate carcasses. $\mathrm{THg}$ concentration in the tissues of primarily carnivorous mammals, including raccoon dogs (Nyctereutes procyonoides), badgers (Meles meles), pine martens (Martes martes), and polecat (Mustela putorius), varied from 40 to $230 \mathrm{ng} \mathrm{g}^{-1} \mathrm{ww}$ in muscles and from 10 to $100 \mathrm{ng} \mathrm{g}^{-1} \mathrm{ww}$ in livers (Kalisińska et al. 2009). In mammals closely related to aquatic environments, and feeding mainly on fish, such as the Eurasian otter (Lutra lutra) and the American mink (Neovison vison), the average $\mathrm{THg}$ concentration in muscle tissues was the highest and amounted to 972 and $2801 \mathrm{ng} \mathrm{g}^{-1} \mathrm{ww}$, respectively (Kalisińska et al. 2012, 2017). As in the muscles, the average $\mathrm{THg}$ concentration in the livers of animals increased with trophic level from $2 \mathrm{ng} \mathrm{g}^{-1} \mathrm{ww}$ in herbivorous rabbits to $3650 \mathrm{ng} \mathrm{g}^{-1} \mathrm{ww}$ in piscivorous American minks (Fig. 5b). However, in the livers of mostly herbivorous and piscivorous animals, the $\mathrm{THg}$ concentration was higher than in muscles. The liver can accumulate $\mathrm{Hg}$ and plays an important role in its storage, redistribution, detoxification, and transformation. In mammals and birds, the liver is a major site for selenium induced $\mathrm{Hg}$ demethylation via the formation of $\mathrm{HgSe}$ (Lyytikäinen et al. 2015; Kalisińska et al. 2017). Moreover, the THg concentration in the tissues of piscivores were several orders of magnitude higher compared to herbivores. It reflects the $\mathrm{Hg}$ biomagnification occurring through diet, with a greater effect noticed in animals at higher trophic levels compared to those at lower trophic levels.

Herbivorous terrestrial mammals tend to have a very low contribution of $\mathrm{MeHg}$ in $\mathrm{THg}$. As shown by research from Canada, in small grazers, like the hare, $\mathrm{MeHg}$ constituted about $3 \%$ of $\mathrm{THg}$ in muscles and $13 \%$ in livers. In the muscles of herbivore moose, the percentage of $\mathrm{MeHg}$ was slightly higher amounting to $13 \%$ (Golzadeh et al. 2020). In the case of roe deer from Slovenia, the percentage of $\mathrm{MeHg}$ was about $10 \%$ in muscles and $40 \%$ in livers (Gnamuš et al., 2020). Studies conducted in Northern America indicated that tissues of animals placed higher in the food chain, such as omnivorous ground squirrel and bear had a similar share of $\mathrm{MeHg}$ in $\mathrm{THg}$ to herbivores (Lasorsa and Allen-Gil 1995; Golzadeh et al. 2020). In the case of fish-eating mammals, such as mink and otter, the increase in the $\mathrm{MeHg}$ contribution to $\mathrm{THg}$ in their tissues and organs was significant and reached about $90 \%$ in the muscles and 60-80\% in the livers (Evans et al. 2000; Strom 2008).

The impact of the pollution of the habitats of wild animals: the red deer, the roe deer and the wild boar on $\mathrm{THg}$ concentration in their muscles and livers was not significant (Table 1). Even in highly industrialised areas, such as the Upper Silesian Coal Basin (USCB), characterised by the presence of numerous hard coal mines and smelters (Fig. 2); the Bełchatów Industrial District (BID) with the largest lignite power plants in Europe and an open-cast mine; the Legnica-Głogów Copper District (LGCD), a copper mining and processing area, the $\mathrm{THg}$ concentration in animals was not much higher than in other regions (i.e. Falandysz 1994a; Szkoda et al. 2012; Durkalec et al. 2015, 2017, 2019). This is probably related to the $\mathrm{Hg}$ retention in the soil that protects the ecosystem from the full effect of the anthropogenic $\mathrm{Hg}$ atmospheric deposition (Bishop et al. 2009). As a result, the $\mathrm{Hg}$ transfer from soil into the food chain is limited. Concerning other areas of Europe, the $\mathrm{THg}$ concentration in the muscles of deer in Poland was higher than in Spain and Croatia (Table S3b). $\mathrm{THg}$ concentration in the muscles of wild boars from Poland was comparable to the THg level in the territory of Croatia and Lithuania, but it was almost three times lower than in Slovakia and central Spain (Table S3b). The current maximum allowable level of $\mathrm{THg}$ in meat derived from wild terrestrial vertebrates set by EU is $40 \mathrm{ng} \mathrm{g}^{-1} \mathrm{ww}$, except for wild boar liver, where the level is $100 \mathrm{ng} \mathrm{g}^{-1}$ ww. Given the available research results and the low annual intake of venison in Poland, the $\mathrm{THg}$ concentration found in the muscle and liver of wild animals should not pose a threat to consumer health.

\section{Livestock}

Exposure of livestock to $\mathrm{Hg}$ depends on how they are kept and what breeding measures are used (EFSA 2008). An additional contribution, in particular for ruminants, may be constituted by the direct soil consumption, which can reach up to $40 \%$ of dry matter food intake (Smith et al. 2009). The average $\mathrm{THg}$ concentration in livestock muscles ranged from 1 to $6 \mathrm{ng} \mathrm{g}^{-1} \mathrm{ww}$ depending on the species (Fig. 5c). The lowest $\mathrm{THg}$ level was found in the muscles of cattle, chickens, rabbits, geese and pigs. The THg concentration in the muscles of cattle in Poland was similar to those found in Spain, 5 times lower than in Sweden and 20 times lower compared to cattle from the Czech Republic (Table S3c). According to current regulations, the EU maximum level of $\mathrm{THg}$ permissible in the meat of livestock is $10 \mathrm{ng} \mathrm{g}^{-1} \mathrm{ww}$, whereas in offal it is $20 \mathrm{ng} \mathrm{g}^{-1} \mathrm{ww}$. The assessment of $\mathrm{THg}$ concentration in the muscle and liver of 
Table 1 Total $\mathrm{Hg}(\mathrm{THg})$ concentration (ng g $\left.{ }^{-1} \mathrm{ww}\right)$ in muscle and liver of wild terrestrial animals from different regions of Poland: a red deer, b roe deer, and c wild boar $\left({ }^{1}\right.$ Szkoda and Żmudzki 2001; ${ }^{2}$ Falandysz and Gajda $1988 ;{ }^{3}$ Falandysz $1994 a ; ~{ }^{4}$ Dobrowolska and Melosik 2002;

${ }^{5}$ Giżejewska et al. 2017; ${ }^{6}$ Albińska et al. 2011; ${ }^{7}$ Szkoda et al. 2012; ${ }^{8}$ Durkalec et al. 2015; ${ }^{9}$ Lech and Gubała 1998; ${ }^{10}$ Sobańska 2005)

\begin{tabular}{|c|c|c|c|c|c|c|c|c|c|c|c|}
\hline & & \multirow[t]{2}{*}{ Region } & & \multirow[t]{2}{*}{ Period } & \multicolumn{3}{|c|}{ Muscle } & \multicolumn{3}{|c|}{ Liver } & \multirow[t]{2}{*}{ Reference } \\
\hline & & & & & $\mathrm{N}$ & Mean & Range & $\mathrm{N}$ & Mean & Range & \\
\hline \multirow[t]{16}{*}{ A) } & Red deer & & Unknown & 1998 & 74 & 2.0 & $<10.0$ & & & & $1^{*}$ \\
\hline & Cervus elaphus & & & 1999 & 82 & 3.0 & $<32.0$ & 218 & 6.0 & & $1^{*}$ \\
\hline & & & & 2000 & 62 & 1.0 & $<7.0$ & & & & $1^{*}$ \\
\hline & & UP & Northern & 1985-1986 & 76 & 2.0 & $1.0-24.0$ & & & & 2 \\
\hline & & & & 1987 & 102 & 1.1 & $0.9-10.0$ & 28 & 8.3 & $2.2-17.0$ & 3 \\
\hline & & & & 1988 & 87 & 1.9 & $0.4-7.7$ & 32 & 9.1 & $2.0-35.0$ & 3 \\
\hline & & & & 1989 & 78 & 0.8 & $0.3-2.2$ & 10 & 3.5 & $2.0-5.9$ & 3 \\
\hline & & & & 1990 & 76 & 0.9 & $0.3-3.3$ & 10 & 2.7 & $2.0-3.3$ & 3 \\
\hline & & & & 1991 & 60 & 1.3 & $0.3-3.5$ & & & & 3 \\
\hline & & & Northwestern & 2000-2001 & & & & 6 & 6.3 & $4.0-12.0$ & 4 \\
\hline & & & Northeastern & 2013-2014 & 14 & 1.0 & $0.1-2.0$ & 14 & 7.0 & $0.1-48.0$ & 5 \\
\hline & & $\mathrm{P}$ & BID & 2009 & 6 & 5.4 & $2.0-8.6$ & 3 & 17.2 & $4.7-32.0$ & 6 \\
\hline & & & & 2010 & 18 & 1.8 & $0.1-5.9$ & 4 & 6.7 & $2.6-10.6$ & 6 \\
\hline & & & & 2011-2012 & & 0.1 & & & 3.0 & & 7 \\
\hline & & & USCB & 2011-2012 & & 1.0 & & & 7.0 & & 7 \\
\hline & & & LGCD & 2011-2012 & & 0.1 & & & 1.0 & & 7 \\
\hline \multirow[t]{18}{*}{ B) } & Roe deer & & unknown & 1998 & 131 & 3.0 & $<28.0$ & & & & $1^{*}$ \\
\hline & Capreolus capreolus & & & 1999 & 140 & 2.0 & $<30.0$ & 398 & 7.0 & & $1^{*}$ \\
\hline & & & & 2000 & 127 & 3.0 & $<19.0$ & & & & $1^{*}$ \\
\hline & & UP & Northern & $1985-1986$ & 102 & 2.0 & $1.0-13.0$ & & & & 2 \\
\hline & & & & 1987 & 149 & 1.3 & $0.4-10.0$ & 28 & 10.0 & $2.0-36.0$ & 3 \\
\hline & & & & 1988 & 84 & 2.8 & $0.6-18.0$ & 45 & 10.0 & $1.7-65.0$ & 3 \\
\hline & & & & 1989 & 99 & 1.2 & $0.3-4.5$ & 10 & 6.5 & $2.3-11.0$ & 3 \\
\hline & & & & 1990 & 89 & 1.3 & $0.3-2.5$ & 10 & 11.0 & $1.7-23.0$ & 3 \\
\hline & & & & 1991 & 59 & 1.1 & $0.4-3.5$ & & & & 3 \\
\hline & & & Northeastern & 2011-2012 & & 2.0 & & & 3.0 & & 7 \\
\hline & & & Northeastern & 2011-2013 & 31 & 1.0 & $0.1-9.0$ & 31 & 5.0 & $0.1-25.0$ & 8 \\
\hline & & & Southeastern & 1996 & & & & 14 & 3.3 & $0.0-11.7$ & 9 \\
\hline & & $\mathrm{P}$ & BID & 2009 & 20 & 7.0 & $0.2-18.9$ & 10 & 18.8 & $2.4-45.0$ & 6 \\
\hline & & & & 2011-2012 & & 1.0 & & & 8.0 & & 7 \\
\hline & & & USCB & 2011-2012 & & 3.0 & & & 7.0 & & 7 \\
\hline & & & & 2011-2013 & 26 & 1.0 & $0.1-6.0$ & 25 & 8.0 & $1.0-33.0$ & 8 \\
\hline & & & LGCD & 2011-2012 & & 4.0 & & & 16.0 & & 7 \\
\hline & & & & 2011-2013 & 52 & 3.0 & $0.1-12.0$ & 53 & 9.0 & $0.1-61.0$ & 8 \\
\hline \multirow[t]{12}{*}{ C) } & Wild boar & & Unknown & 1998 & 186 & 7.0 & & & & & $1^{*}$ \\
\hline & Sus scrofa & & & 1999 & 150 & 6.0 & & 460 & 20.0 & & $1^{*}$ \\
\hline & & & & 2000 & 124 & 7.0 & & & & & $1^{*}$ \\
\hline & & UP & Northern & 1985-1986 & 102 & 4.0 & $1.0-11.0$ & 2 & 41.0 & $38.0-44.0$ & 2 \\
\hline & & & & 1987 & 168 & 4.0 & $0.5-28.0$ & 43 & 14.0 & $3.0-29.0$ & 3 \\
\hline & & & & 1988 & 118 & 5.2 & $0.8-23.0$ & 57 & 18.0 & $4.8-42.0$ & 3 \\
\hline & & & & 1989 & 116 & 3.0 & $0.6-8.6$ & 10 & 13.0 & $6.7-23.0$ & 3 \\
\hline & & & & 1990 & 119 & 1.9 & $0.6-5.1$ & 12 & 7.5 & $4.5-12.0$ & 3 \\
\hline & & & & 1991 & 69 & 2.3 & $0.5-6.2$ & & & & 3 \\
\hline & & & Northeastern & 1998-2000 & & & & 17 & 9.0 & $5.0-22.0$ & 10 \\
\hline & & & & 2011-2012 & & 6.0 & & & 37.0 & & 7 \\
\hline & & & & 2011-2013 & 61 & 6.0 & $0.1-20.0$ & 60 & 19.0 & $3.0-28.0$ & 8 \\
\hline
\end{tabular}


Table 1 continued

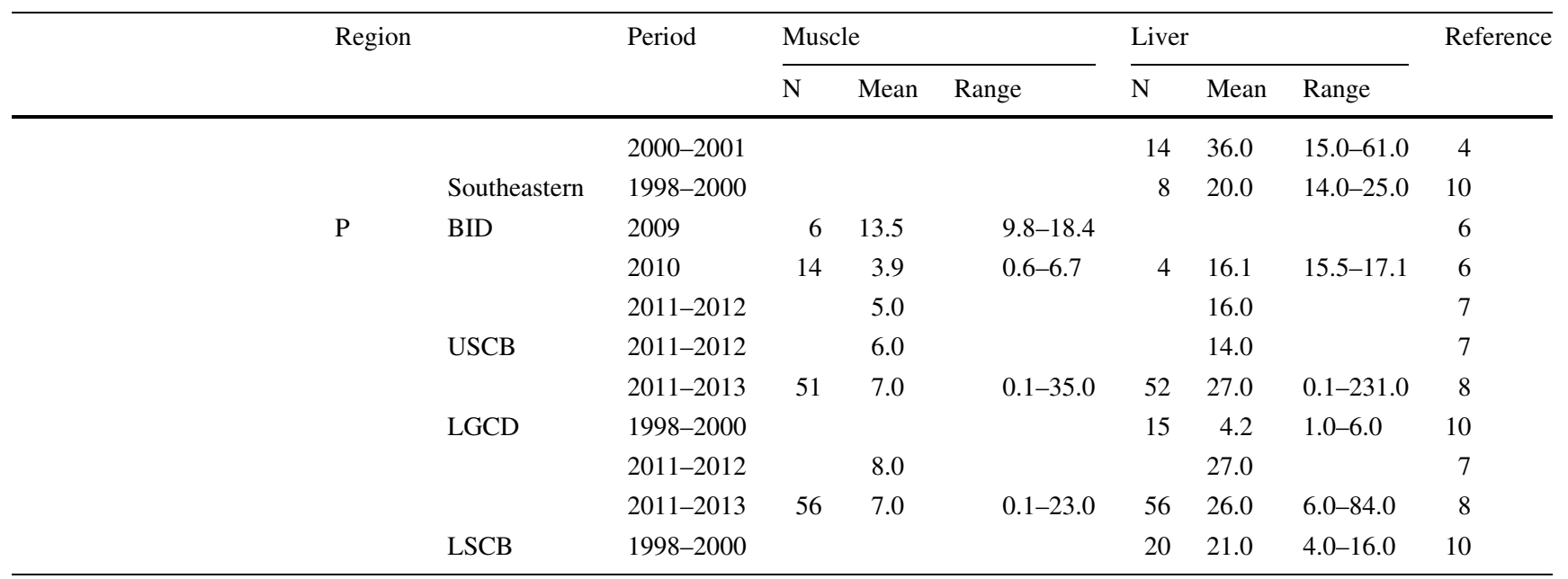

UP unpolluted area, $P$ polluted area, USCB Upper Silesian Coal Basin, LSCB Lower Silesian Coal Basin, BID Bełchatów Industrial District, $L G C D$ Legnica-Głogów Copper District (to view locations, see Fig. 2)

*The minimum values were not given in this work

cattle and pigs carried out on behalf of the Polish government in 2009-2018 showed that only $0.4 \%$ of results were not acceptable. Therefore, the consumption of the meat of slaughter animals does not pose a significant threat to the health of consumers (Nawrocka et al. 2020). Probably due to the non-hazardous THg level in the Polish livestock, the $\mathrm{Hg}$ speciation was not examined. As shown by the study conducted in China, the share of $\mathrm{MeHg}$ in $\mathrm{THg}$ in poultry was low. For chicken, duck, and goose muscles it was up to 15,25 , and $40 \%$, respectively. An even smaller proportion of $\mathrm{MeHg}$ was detected in livers of those birds, in which it did not exceed $20 \%$ THg (Yin et al. 2017). The poultry investigated in the aforementioned work was fed only with crops and vegetables, while in most European countries, including Poland, livestock feed is supplemented with fish meal. Therefore, meat from animals fed with fish meal or other fish products is likely to contain more $\mathrm{MeHg}$ (Lindberg et al. 2004).

\section{Temporal trends of biotic $\mathrm{Hg}$}

To estimate the time trends in biotic $\mathrm{THg}$, this study presents only results of research from the period for which reliable data on $\mathrm{Hg}$ emission in Poland are available. Consequently, the paper refers to data published in the last three decades. For Poland, this period was not only a time of socio-political transformation, but also a time of changes in the industrial structure, the development of technology and science, and an increase in ecological awareness.

This section presents the temporal changes in $\mathrm{Hg}$ concentration in terrestrial plants (Sect. Terrestrial plants) based on the tree leaves results, and animals (Sect. Wild animals and livestock): game, including cervids and wild boar, and livestock, in particular cattle and pigs.

\section{Terrestrial plants}

The collected data do not provide sufficient information to discuss the long-term variability of $\mathrm{THg}$ concentration in terrestrial plants. The available data on the THg level in the leaves of linden (Fig. 6a) and maple (Fig. 6b) may indicate a downward trend. The mean THg concentration in linden leaves decreased from $134 \mathrm{ng} \mathrm{g}^{-1}$ in 2005 to $10 \mathrm{ng} \mathrm{g}^{-1} \mathrm{dw}$ in 2019, which represents a decrease of $10 \mathrm{ng} \mathrm{g}^{-1} \mathrm{dw}$ per year. In the case of maple leaves, the mean THg concentration dropped from $90 \mathrm{ng} \mathrm{g}^{-1} \mathrm{dw}$ measured in 2005 to less than $50 \mathrm{ng} \mathrm{g}^{-1} \mathrm{dw}$ in 2013 which gives a gradient of just under $7 \mathrm{ng} \mathrm{g}^{-1} \mathrm{dw}$ year $^{-1}$. THg concentration measured in linden leaves in 2005-2019 corresponded quite well with changes in $\mathrm{Hg}$ emissions $(r=0.87)$, which indicates their potential use as a bioindicator (Kowalski et al. 2012). Due to the small number of observations, the trends and correlations determined were statistically insignificant $(p>0.05)$.

The decrease in $\mathrm{THg}$ concentration in terrestrial vegetation may also be demonstrated by the values measured in moss, considered to be an environmental indicator. In the paper by Harmens et al. (2008), the THg concentration in samples from Poland in 1995 was very high and mostly exceeded $200 \mathrm{ng} \mathrm{g}^{-1} \mathrm{dw}$ in almost every area of the country. Besides, the values presented for Poland were much higher than $\mathrm{THg}$ concentration measured in mosses collected in the same year in neighbouring countries. The results of research conducted in Poland in 2010-2012 indicate a decrease of more than tenfold in $\mathrm{THg}$ 
(a)

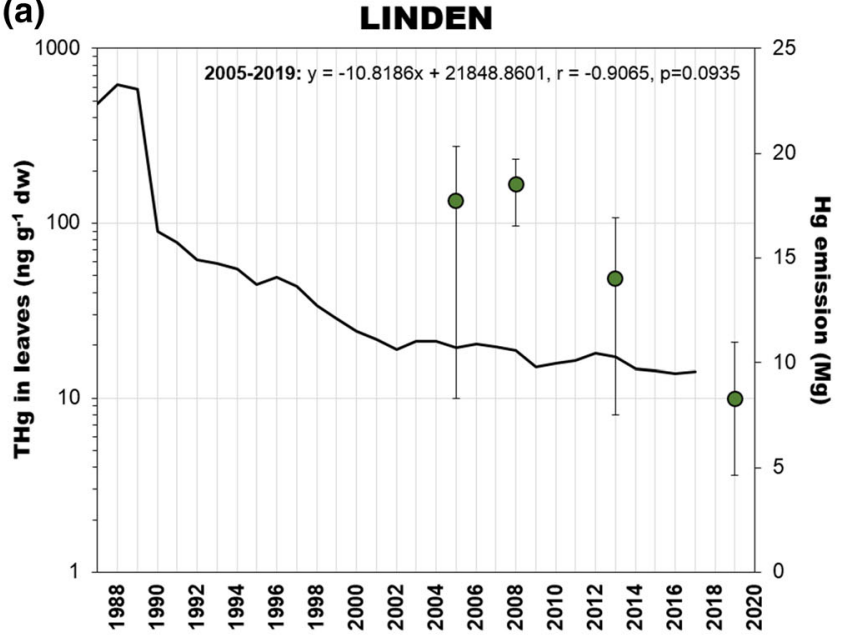

(c)

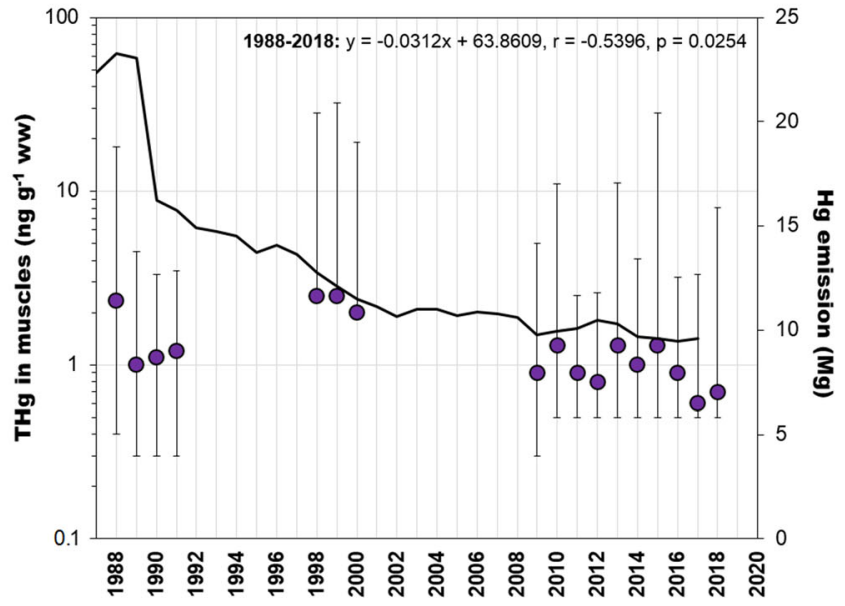

(b) MAPLE

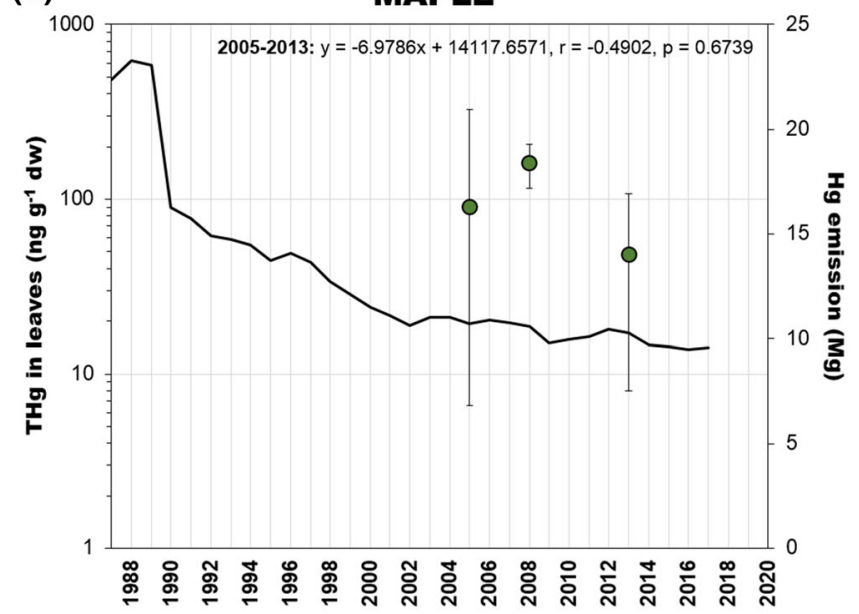

(d)

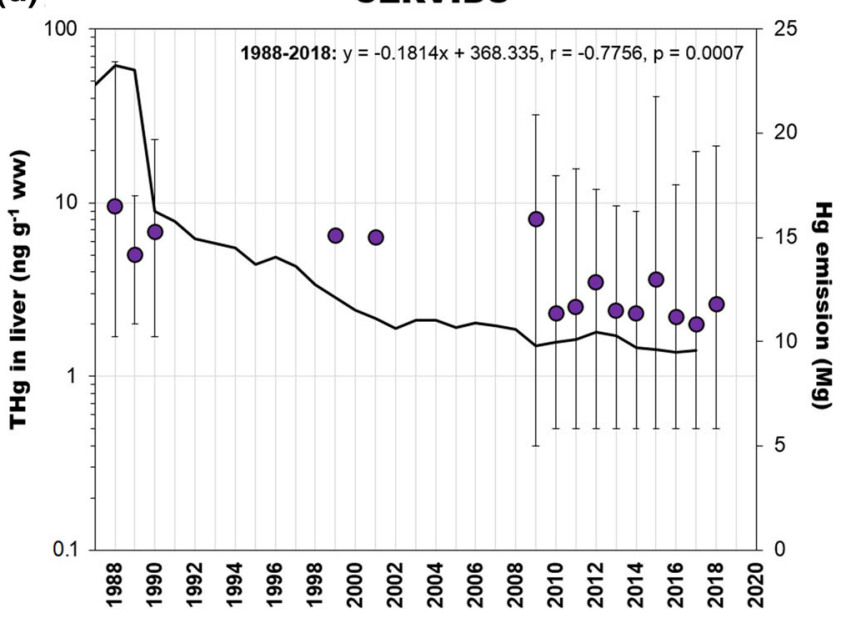

(f)

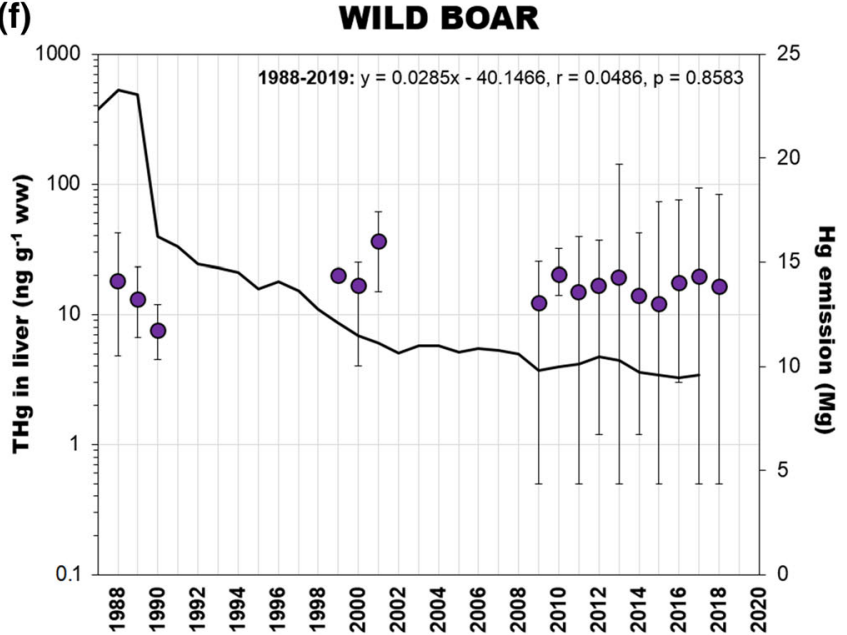

(e)

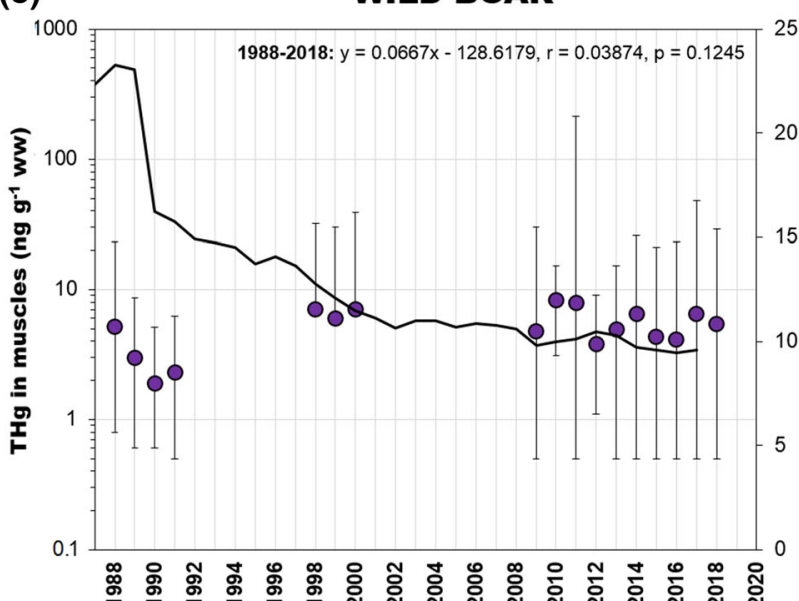

25

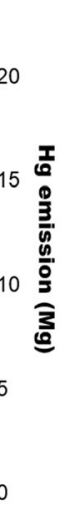

Fig. 6 Temporal changes of total $\mathrm{Hg}\left(\mathrm{THg}\right.$ ) concentration (mean and range) in terrestrial vegetation: a linden and $\mathbf{b}$ maple leaves (ng $\mathrm{g}^{-1} \mathrm{dw}$ ) muscles and livers of wild terrestrial animals: $\mathbf{c}, \mathbf{d}$ cervids and $\mathbf{e}, \mathbf{f}$ wild boar (ng g ${ }^{-1} \mathrm{ww}$ ) from Poland in relation to the anthropogenic emission of $\mathrm{Hg}$ (values and references are given in the Table S5). The data on the $\mathrm{Hg}$ national emission were taken from the KOBiZE (2019) inventory 
concentration in moss in unpolluted areas and a fourfold decrease in contaminated areas compared to 1995. The measured values were also lower than $\mathrm{THg}$ concentration in moss in most other European countries (Table S2).

\section{Wild animals and livestock}

Research conducted in the years 1988-2018 showed decreasing $\mathrm{THg}$ trends in muscle and liver of cervids (Fig. 6c, d). In these herbivorous animals, changes in $\mathrm{THg}$ concentration were correlated with the level of $\mathrm{Hg}$ emission (Table 2). The significant decrease in $\mathrm{Hg}$ emissions that occurred in the last decade of the previous century (Fig. 1) probably caused a decrease in the $\mathrm{Hg}$ concentration in plants (Fig. 6a, b) reducing the exposure of herbivorous red deer and roe deer. This is also indicated by statistically significant differences in $\mathrm{THg}$ concentration in cervids between periods with different $\mathrm{Hg}$ emission (Fig. S2), both for muscle and liver (Table 3). For both tissues, Hg concentrations during the period of stabilised $\mathrm{Hg}$ emission were about 2 times lower than before. Contrary to cervids, a negative relationship between $\mathrm{Hg}$ emission and $\mathrm{THg}$ concentration was found in the muscles of wild boar
(Table 2; Fig. 6e). In the case of wild boar liver, the $\mathrm{THg}$ concentrations were not dependent on time or $\mathrm{Hg}$ emission (Table 2; Fig. 6f). For both tissues, differences in $\mathrm{Hg}$ concentration during periods with different $\mathrm{Hg}$ emission, were not statistically significant (Table 3). To indicate possible causes affecting strong fluctuations in THg concentration in wild boar in recent years, more samples from different regions of Poland and differences in age of animals in individual years should be presented. Another possible explanation may be the large diversity of food consumed by wild boar in their living areas. The diet of wild boar consists mainly of plants, but also the food of animal origin, among others carrion, invertebrates, birds and small mammals. Moreover, their diet changes seasonally which differentiates the food exposure to $\mathrm{Hg}$ through the year. The rooting by wild boar' is also a factor that can both increase and decrease the $\mathrm{Hg}$ load entering the animals' body with the soil they ingest from different areas (Fig. 2). The phenomenon of geophagia, defined as consumption of earth or soil-like substances, has been described on the example of ruminants for which soil can account for up to $40 \%$ of dry matter content (Smith et al. 2009). The THg concentrations in wild boar tissues may

Table 2 Relationship between total $\mathrm{Hg}(\mathrm{THg})$ concentration in terrestrial organisms from Poland and the national $\mathrm{Hg}$ emission

\begin{tabular}{llllll}
\hline & & Period & Equation & $\mathrm{r}$ \\
\hline Wild Animals & Wild boar-muscles & $1988-2018$ & $\mathrm{Hg}_{\text {biota }}=0.1625 \mathrm{Hg}_{\text {emission }}+7.3135$ & 0.4709 & 0.0418 \\
& Wild boar-liver & $1988-2018$ & $\mathrm{Hg}_{\text {biota }}=0.2193 \mathrm{Hg}_{\text {emission }}+15.3465$ & 0.1454 & 0.5650 \\
& Cervids-muscles & $1988-2018$ & $\mathrm{Hg}_{\text {biota }}=0.0478 \mathrm{Hg}_{\text {emission }}+0.5577$ & 0.5360 & 0.0266 \\
& Cervids-liver & $1988-2018$ & $\mathrm{Hg}_{\text {biota }}=0.3595 \mathrm{Hg}_{\text {emission }}+0.0444$ & 0.6967 & 0.0027 \\
Livestock & Cattle-muscles & $1988-2018$ & $\mathrm{Hg}_{\text {biota }}=0.0549 \mathrm{Hg}_{\text {emission }}+0.232$ & 0.7164 & 0.0039 \\
& Cattle-liver & $1988-2018$ & $\mathrm{Hg}_{\text {biota }}=0.2101 \mathrm{Hg}_{\text {emission }}-0.0924$ & 0.8184 & 0.0001 \\
& Pig-muscles & $1988-2018$ & $\mathrm{Hg}_{\text {biota }}=0.1257 \mathrm{Hg}_{\text {emission }}-0.5323$ & 0.8476 & 0.0000 \\
& Pig-liver & $1988-2018$ & $\mathrm{Hg}_{\text {biota }}=0.2457 \mathrm{Hg}_{\text {emission }}-1.2032$ & 0.9528 & 0.0000 \\
& & & &
\end{tabular}

Table 3 Results of Mann-Whitney Test and the statistical comparison of total $\mathrm{Hg}(\mathrm{THg})$ concentration in muscle and liver of wild terrestrial animals and livestock in period of stabilised $\mathrm{Hg}$ emission and before. These periods were distinguished on the basis of the data presented in Fig. 1 and Fig. S2

\begin{tabular}{|c|c|c|c|c|}
\hline & & \multicolumn{3}{|c|}{ Mean THg (ng g ${ }^{-1}$ ww) } \\
\hline & & Until 2002 & After 2002 & $p$ \\
\hline \multirow[t]{4}{*}{ Wild animals } & Wild boar-muscles & 4.6 & 5.7 & 0.4642 \\
\hline & Wild boar-liver & 18.5 & 16.3 & 0.7449 \\
\hline & Cervids-muscles & 1.8 & 1.0 & $0.0147 *$ \\
\hline & Cervids-liver & 6.8 & 3.2 & $0.0120^{*}$ \\
\hline \multirow[t]{4}{*}{ Livestock } & Cattle-muscles & 1.3 & 1.1 & 0.2888 \\
\hline & Cattle-liver & 4.6 & 1.8 & $0.0058 *$ \\
\hline & Pig-muscles & 1.8 & 0.7 & $0.0072 *$ \\
\hline & Pig-liver & 3.5 & 1.2 & $0.0058 *$ \\
\hline
\end{tabular}

*The difference between two period is statistically significant at the p-value $<0.05$ 
also have been influenced by processes that are not dosedependent and unrelated to the food intake, such as $\mathrm{Hg}$ detoxification and elimination (Bełdowska and Falkowska 2016).

The meat composition of livestock has been investigated in Poland since the mid-1970s. The obtained results indicate that $\mathrm{THg}$ concentration in tissues of cattle and pigs in the last three decades are getting lower (Fig. 7a, b, c, d). Differences in $\mathrm{THg}$ concentration during and before the stabilisation of $\mathrm{Hg}$ emission were statistically significant for cattle livers, and pig muscles and livers (Table 3). In each of these tissues, the average $\mathrm{THg}$ concentration decreased by more than twofolds. The observed drop in THg concentration in cattle and pig tissues reflects a reduction in $\mathrm{Hg}$ emission, which is confirmed by a significant correlation between $\mathrm{THg}$ concentration in both the liver and muscle of livestock and the level of emission
(Table 2). At the same time, the food exposure of farm animals to $\mathrm{Hg}$ was reduced due to the elimination of plant protection products based on $\mathrm{Hg}$ compounds, which were used for the seeds conservation and field spraying. These substances were withdrawn from the EU market in the late 1970s, however, in Poland Hg was used widely for seed preservation until the 1980s (Falandysz 1994b). The current level of $\mathrm{Hg}$ in cultivated plants may result from the use of some fertilisers or soil amendments (Sánchez-Báscones et al. 2017). In contrast, food additives, fish-based proteins and others, such as protein hydrolysates from poultry and protein made from feathers may constitute an additional source of organic $\mathrm{Hg}$. Inorganic $\mathrm{Hg}$, by contrast, may be present in mineral supplements, but they usually occur in amounts not exceeding the maximum allowable levels of this element (Hedegaard and Sloth 2011). The reduction of THg concentration in tissues of livestock over the years (a)

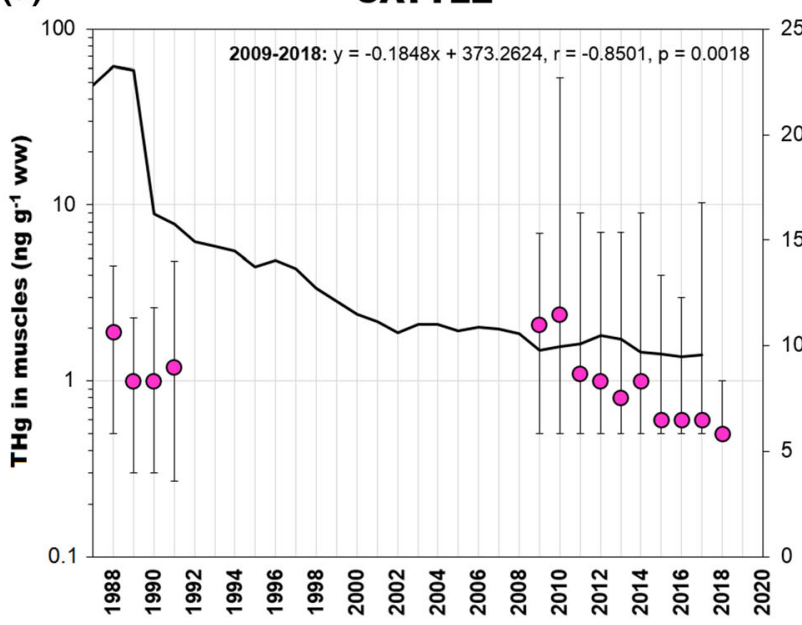

(c)

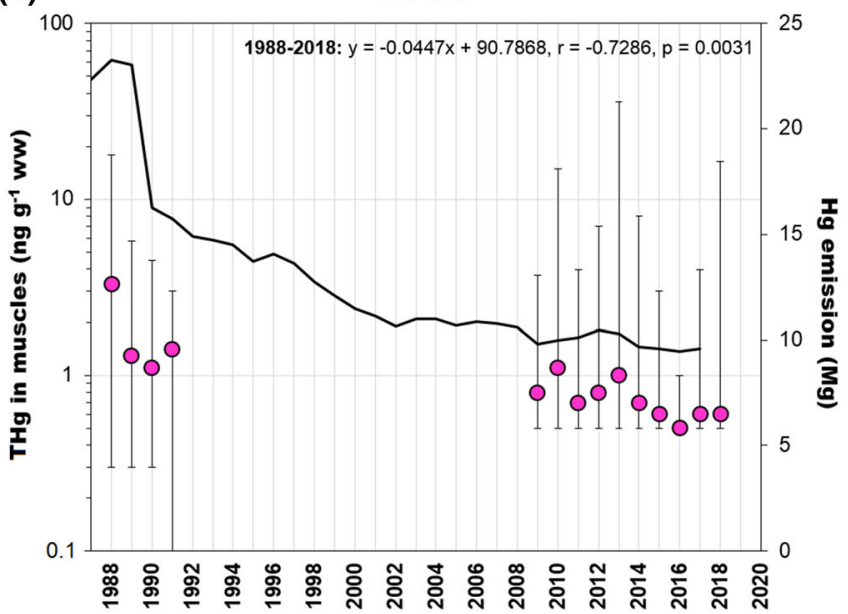

(b)

CATTLE

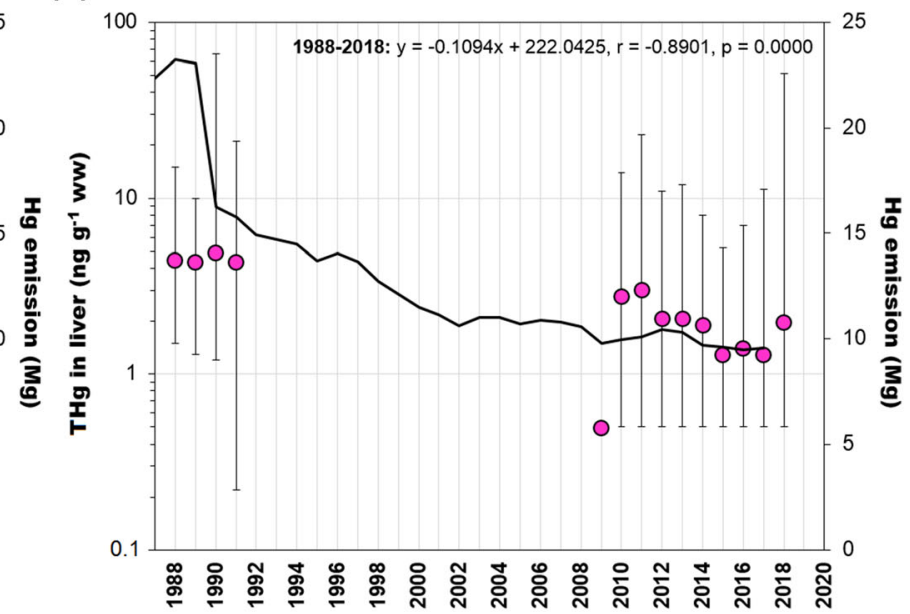

(d)

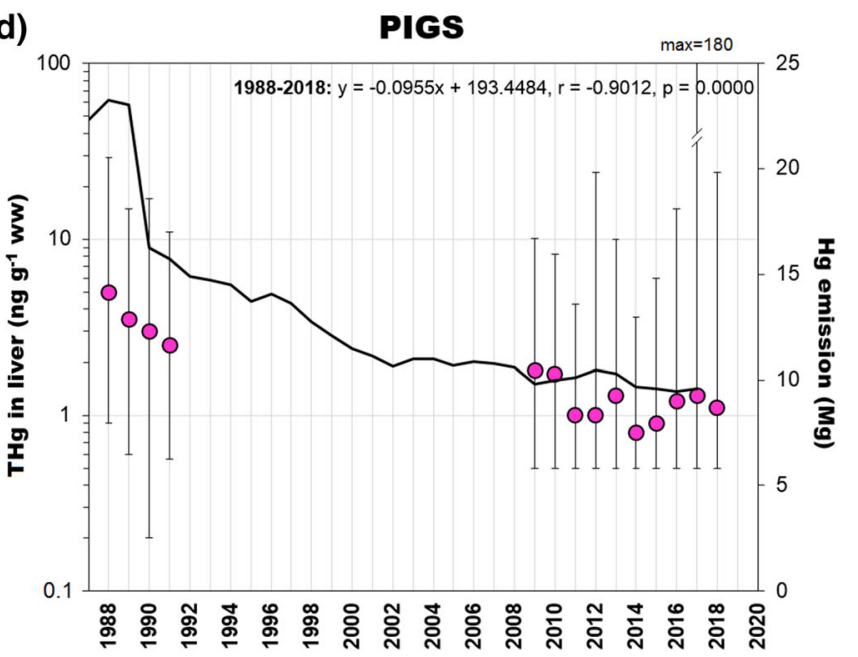

Fig. 7 Temporal changes of total $\mathrm{Hg}\left(\mathrm{THg}\right.$ ) concentration (mean and range) in muscles and livers of livestock: a, b cattle, and $\mathbf{c}, \mathbf{d}$ pigs (ng g $\mathrm{g}^{-1}$ ww) from Poland in relation to the anthropogenic emission of $\mathrm{Hg}$ (values and references are given in the Table S5). The data on the $\mathrm{Hg}$ national emission were taken from the KOBiZE (2019) inventory 
could also be influenced by the EU ban on the use of meat and bone meal (MBM) of mammals in animal feeds. The regulation was introduced in 2001 and applied to all livestock, including fish (EC 2001). The THg level in MBM is generally much higher compared to other animal feeding stuff, especially plant-based ones such as soybean or maize (EFSA 2008).

Among the factors that could significantly contribute to a decrease in THg concentration in livestock, in addition to reduced $\mathrm{Hg}$ emission, one should mention the development of breeding technology and the increase of requirements in the control of contamination levels in fodder and feed materials together with the implementation of analytical methods enabling reduction of costs and examination time. Despite the indication of a downward trend in the $\mathrm{THg}$ level in livestock, the $\mathrm{Hg}$ concentration in the food of animal origin should be constantly monitored to ensure an adequate level of consumer safety.

\section{CONCLUSION}

As indicated in HELCOM (2018) and EMEP (2018) reports, Poland is one of the main emitters of $\mathrm{Hg}$ to the atmosphere among the Baltic Sea region countries. It is also the country where the reduction of $\mathrm{Hg}$ emission is least effective compared to most of Europe (EEA 2019), which proves the urgent need for modernisation and transformations in the energy and industry sectors. However, analyses of organisms inhabiting both the terrestrial and aquatic environment indicated a moderate or low $\mathrm{THg}$ concentration level compared to other places on the globe. This inconsistency may be caused by the insufficient implementation of the atmospheric $\mathrm{Hg}$ monitoring programme in Poland and transfer of these data into global databases. The uncertainty of the international model calculations of atmospheric deposition may result from the lack of accurate data from Polish atmospheric Hg monitoring. Besides the European Monitoring and Evaluation Programme (EMEP), Poland also participates in the Global Atmosphere Watch Programme (GAW) of the World Meteorological Organization and the COMBINE Programme of HELCOM, which provide information on the environmental quality to the public and to policy-makers. As a part of the Polish State Environmental Monitoring Programme, measurements of TGM and THg in precipitation are carried out at five background stations, which are evenly distributed throughout the country. However, only one of these stations, located in the northeastern part of the country, is in compliance with the EMEP requirements. Therefore, the amount of valuable data from Polish monitoring included in the international network is insufficient, making model results verification very difficult. The need for validation and calibration of the models used in the most sensitive areas is notable. The another reason of low THg concentration in terrestrial organisms is probably connected with relatively low bioavailability of $\mathrm{Hg}$ in abiotic compartments. It is likely that $\mathrm{Hg}$ deposited on Polish territory is retained in a less mobile form, mainly bound in organic-rich soils. Environmental conditions in Poland indicate that in soils, its dominant form is inorganic $\mathrm{Hg}$, which is only slightly transformed into MeHg. Consequently, this limits the $\mathrm{Hg}$ uptake by terrestrial biota and makes the organic-rich topsoil the main $\mathrm{Hg}$ storage in Poland. However, considering the direction of environmental changes, related mainly to the climate, it is forecast that as a result of remobilisation, the $\mathrm{Hg}$ outflow from the soil to rivers and consequently into the sea may intensify in the next few years. It is crucial for inland and coastal waters, for which rivers constitute a major source of $\mathrm{Hg}$.

The research and monitoring of current status and trends of THg contamination in terrestrial organisms in Poland are still insufficient, especially when compared with countries such as Sweden or Canada, where regular monitoring of $\mathrm{Hg}$ pollution, including the use of bioindicators, began already in the 1960s (www.ivl.se). The authors selected organisms that can be bioindicators of THg pollution and be useful for identification of $\mathrm{Hg}$ 'hot-spots', namely brown birch bolete mushroom (Luccinum scabrum) and herbivorous wild animals, mainly deer (Cervidae). Although the recent THg level in fish and wild animals from Poland poses no risk to consumers, systematic and thoughtful monitoring is necessary, as it would allow the prediction of the consequences of climate change on the $\mathrm{Hg}$ cycle in the environment and the effects of this process on humans. This fully complies with the provisions of the Minamata Convention.

Acknowledgements This research was financed by the Polish Ministry of Science and Higher Education within the framework of the research Project No. N N304 161637 and project financed by the National Science Centre No. 2015/17/B/ST10/03418. Results presented in the paper were initially discussed at a Specialty Workshop, organised during the 14th International Conference on Mercury as a Global Pollutant (ICMGP) in Krakow, Poland, from 8 to 13 September, 2019.

Open Access This article is licensed under a Creative Commons Attribution 4.0 International License, which permits use, sharing, adaptation, distribution and reproduction in any medium or format, as long as you give appropriate credit to the original author(s) and the source, provide a link to the Creative Commons licence, and indicate if changes were made. The images or other third party material in this article are included in the article's Creative Commons licence, unless indicated otherwise in a credit line to the material. If material is not included in the article's Creative Commons licence and your intended use is not permitted by statutory regulation or exceeds the permitted use, you will need to obtain permission directly from the copyright holder. To view a copy of this licence, visit http://creativecommons. org/licenses/by/4.0/. 


\section{REFERENCES}

Albińska, J., J. Góralski, M.I. Szynkowska, E. Leśniewska, and T. Paryjczak. 2011. Mercury in carcasses of wild animals hunted in the province of Lodz. Rocznik Ochrona Srodowiska 13: 525-538.

Baralkiewicz, D., H. Gramowska, and R. Godyn. 2006. Distribution of total mercury and methylmercury in water, sediment and fish from Swarzdzkie lake. Chemistry and Ecology 22: 59-64. https://doi.org/10.1080/02757540500393935.

Bargagli, R. 2016. Moss and lichen biomonitoring of atmospheric mercury: A review. Science of The Total Environment 572: 216-231. https://doi.org/10.1016/j.scitotenv.2016.07.202.

Bełdowska, M., and L. Falkowska. 2016. Mercury in marine fish, mammals, seabirds, and human hair in the coastal zone of the southern Baltic. Water, Air, and Soil Pollution 227: 52. https:// doi.org/10.1007/s11270-015-2735-5.

Bełdowska, M., A. Jędruch, L. Łęczyński, D. Saniewska, and U. Kwasigroch. 2016. Coastal erosion as a source of mercury into the marine environment along the Polish Baltic shore. Environmental Science and Pollution Research 23: 16375-16382. https://doi.org/10.1007/s11356-016-6753-7.

Bishop, K., C.J. Allan, L. Bringmark, E. Garcia, S. Hellsten, L. Högbom, L. Johansson, A. Lomander, et al. 2009. Forestry's contribution to $\mathrm{Hg}$ bioaccumulation in freshwaters: assessment of the available evidence. In Does forestry contribute to mercury in Swedish fish?, ed. Y. Nordin, 9-24. Stockholm: KSLAT.

Bishop, K., J.B. Shanley, A. Riscassi, H.A. de Wit, K. Eklöf, B. Meng, C. Mitchell, S. Osterwalder, et al. 2020. Recent advances in understanding and measurement of mercury in the environment: Terrestrial Hg cycling. Science of The Total Environment https://doi.org/10.1016/j.scitotenv.2020.137647.

Braaten, H.F.V., H.A. de Wit, E. Fjeld, S. Rognerud, E. Lydersen, and T. Larssen. 2014. Environmental factors influencing mercury speciation in Subarctic and Boreal lakes. Science of The Total Environment 476-477: 336-345. https://doi.org/10.1016/j. scitotenv.2014.01.030.

Braaten, H.F.V., S. Åkerblom, K.K. Kahilainen, M. Rask, J. Vuorenmaa, J., Mannio, T. Malinen, E. Lydersen, et al. 2019. Improved Environmental Status: 50 Years of Declining Fish Mercury Levels in Boreal and Subarctic Fennoscandia. Environmental Science and Technology 53: 1834-1843. https://doi. org/10.1021/acs.est.8b06399.

Bravo, A.G., D.N. Kothawala, K. Attermeyer, E. Tessier, P. Bodmar, J.L.J. Lefesma, J. Audet, J.P. Casas-Ruiz, et al. 2018. The interplay between total mercury, methylmercury and dissolved organic matter in fluvial systems: A latitudinal study across Europe. Water Research 144: 172-182. https://doi.org/10.1016/j. watres.2018.06.064.

Danielsson, S., J. Hedman, A. Miller, and A. Bignert. 2011. Mercury in Perch from Norway, Sweden and Finland - Geographical Patterns and Temporal Trends. Swedish Museum of Natural History, Report 8/2011, Stockholm, Sweden.

De Nicola, F., V. Spagnuolo, D. Baldantoni, L. Sessa, A. Alfani, R. Bargagli, F. Monaci, S. Terracciano, et al. 2013. Improved biomonitoring of airborne contaminants by combined use of holm oak leaves and epiphytic moss. Chemosphere 92: 1224-1230. https://doi.org/10.1016/j.chemosphere.2013.04.050.

Dobrowolska, A., and M. Melosik. 2002. Mercury contents in liver and kidneys of wild boar (Sus scrofa) and red deer (Cervus elaphus). Zeitschrift für Jagdwissenschaft 48: 156-160.

Driscoll, C.T., J. Holsapple, C.L. Schofield, and R. Munson. 1998. The chemistry and transport of mercury in a small wetland in the Adirondack region of New York, USA. Biogeochemistry 40: 137-146. https://doi.org/10.1023/A:1005989229089.
Durkalec, M., J. Szkoda, R. Kolacz, S. Opalinski, A. Nawrocka, and J. Żmudzki. 2015. Bioaccumulation of Lead, Cadmium and Mercury in Roe Deer and Wild Boars from Areas with Different Levels of Toxic Metal Pollution. International Journal of Environmental Research 9: 205-211. https://doi.org/10.22059/ IJER.2015.890.

Durkalec, M., R. Kolenda, T. Owczarek, J. Szkoda, A. Nawrocka, J. Grzegrzółka, P. Dzięgiel, P. Socha, et al. 2017. Expression of metallothionein in the liver and kidneys of the red deer (Cervus elaphus L.) from an industrial metal smelting area of Poland. Ecotoxicology and Environmental Safety 137: 121-129. https:// doi.org/10.1016/j.ecoenv.2016.11.018.

Durkalec, M., A. Nawrocka, J. Żmudzki, A. Filipek, M. Niemcewicz, and A. Posyniak. 2019. Concentration of Mercury in the Livers of Small Terrestrial Rodents from Rural Areas in Poland. $\begin{array}{llll}\text { Molecules 24: } 4108 . & \text { https://doi.org/10.3390/ }\end{array}$ molecules 24224108 .

EC. 2001. Regulation 999/2001 of the European Parliament and of the Council of 22 May 2001 laying down rules for the prevention, control and eradication of certain transmissible spongiform encephalopathies. OJ L 147: 1-40. http://data.europa.eu/eli/reg/ 2001/999/oj

EC, 2008. Directive 2008/105 of the European Parliament and of the Council of 16 December 2008 on environmental quality standards in the field of water policy. OJ L 348: 84-97. http:// data.europa.eu/eli/dir/2008/105/oj

EC. 2017. Regulation 2017/852 of the European Parliament and of the Council of 17 May 2017 on mercury. OJ L 137: 1-21. http://data. europa.eu/eli/reg/2017/852/oj

EEA. 2018. European waters. Assessment of status and pressures. https://doi.org/10.2800/303664.

EEA. 2019. Data and maps catalogue. Retrieved 25 September, 2020, from https://www.eea.europa.eu/data-and-maps/daviz/changein-emissions-of-heavy-metals

EFSA. 2008. Mercury as undesirable substance in animal feed Scientific opinion of the Panel on Contaminants in the Food Chain. EFSA Journal 6: 654. https://doi.org/10.2903/j.efsa.2008. 654.

Eklöf, K., J. Fölster, L. Sonesten, and K. Bishop. 2012. Spatial and temporal variation of $\mathrm{THg}$ concentrations in run-off water from 19 boreal catchments, 2000-2010. Environmental Pollution 164: 102-109. https://doi.org/10.1016/j.envpol.2012.01.024.

EMEP. 2016. Atmospheric Supply of Nitrogen, Cadmium, Mercury, Benzo(a)pyrene and PBDEs to the Baltic Sea in 2014. Technical Report MSC-W 1/2016, Oslo, Norway.

EMEP. 2018. Atmospheric Supply of Nitrogen, Cadmium, Mercury, Benzo(a)pyrene, and PCB-153 to the Baltic Sea in 2016. Technical Report MSC-W 1/2018, Oslo, Norway.

Emmerton, C.A., C.A. Cooke, G.R. Wentworth, J.A. Graydon, A. Ryjkov, and A. Dastoor. 2018. Total Mercury and Methylmercury in Lake Water of Canada's Oil Sands Region. Environmental Science and Technology 52: 10946-10955. https://doi. org/10.1021/acs.est.8b01680.

Evans, R.D., and E.M., Addison, J.Y. Villeneuve, K.S. MacDonald, and D.G. Joachim. 2000. Distribution of Inorganic and Methylmercury among Tissues in Mink (Mustela vison) and Otter (Lutra canadensis). Environmental Research 84: 133-139. https://doi.org/10.1006/enrs.2000.4077.

Falandysz, J. 1994a. Some toxic and trace metals in big game hunted in the northern part of Poland in 1987-1991. Science of The Total Environment 141: 59-73. https://doi.org/10.1016/00489697(94)90018-3.

Falandysz, J. 1994b. The Uses of Pesticides and Their Levels in Food in Eastern Europe: The Example of Poland. In Contaminants in the Environment: A Multidisciplinary Assessment of Risks to 
Man and Other Organisms, ed. A. Renzoni, N. Mattei, L. Lari, and C. Fossi, 247-256. Boca Raton: CRC Press.

Falandysz, J., and L. Bielawski. 2007. Mercury and its bioconcentration factors in Brown Birch Scaber Stalk (Leccinum scabrum) from various sites in Poland. Food Chemistry 105: 635-640. https://doi.org/10.1016/j.foodchem.2007.04.024.

Falandysz, J., and A. Chwir. 1997. The concentrations and bioconcentration factors of mercury in mushrooms from the Mierzeja Wiślana sand-bar, Northern Poland. Science of The Total Environment 203: 221-228. https://doi.org/10.1016/s00489697(97)00150-2.

Falandysz, J., and B. Gajda. 1988. Mercury content in muscle, liver and kidneys of slaughtered and game animals from the northern part of Poland, 1985-1986. Roczniki PZH 39: 113-117.

Falandysz, J., M. Kawano, A. Swieczkowski, A. Brzostowski, and M. Dadej. 2003. Total mercury in wild-grown higher mushrooms and underlying soil from Wdzydze Landscape Park, Northern Poland. Food Chemistry 81: 21-26. https://doi.org/10.1016/ S0308-8146(02)00344-8

Falandysz, J., A. Frankowska, and A. Mazur. 2007. Mercury and its bioconcentration factors in King Bolete (Boletus edulis) Bull Fr. Journal of Environmental Science and Health, Part A 42: 2089-2095. https://doi.org/10.1080/10934520701627058.

Falandysz, J., E. Widzicka, A.K. Kojta, G. Jarzyńska, M. Drewnowska, A. Dryżałowska, D. Danisiewicz-Czupryńska, E. Lenz, et al. 2012. Mercury in Common Chanterelles mushrooms: Cantharellus spp. update. Food Chemistry 133: 842-850. https:// doi.org/10.1016/j.foodchem.2012.01.102.

FOREGS. 2005. Geochemical Atlas of Europe Part 1-Background Information, Methodology and Maps. Espoo: Geological Survey of Finland.

Gajewska, R.E., and M. Nabrzyski. 1977. Mercury, cadmium and lead content in sea and freshwater fish. Roczniki PZH 28: 215-224.

Gębka, K., M. Bełdowska, D. Saniewska, K. Kuliński, and J. Bełdowski. 2018. Watershed characteristics and climate factors effect on the temporal variability of mercury in the southern Baltic Sea rivers. Journal of Environmental Sciences 68: 55-64. https://doi.org/10.1016/j.jes.2017.11.030.

Gębka, K., D. Saniewska, and M. Bełdowska. 2020. Mobility of mercury in soil and its transport into the sea. Environmental Science and Pollution Research 27: 8492-8506. https://doi.org/ 10.1007/s11356-019-06790-8.

Giżejewska, A., J. Szkoda, A. Nawrocka, J. Żmudzki, and Z. Giżejewski. 2017. Can red deer antlers be used as an indicator of environmental and edible tissues' trace element contamination? Environmental Science and Pollution Research 24: 11630-11638. https://doi.org/10.1007/s11356-017-8798-7.

Gnamuš, A., A.R. Bryne, and M. Horvat. 2000. Mercury in the SoilPlant-Deer-Predator Food Chain of a Temperate Forest in Slovenia. Environmental Science and Technology 34: 3337-3347. https://doi.org/10.1021/es991419w.

Golzadeh, N., B.D. Brast, N. Basu, J.M. Baker, and J.C. Auger. 2020. Evaluating the concentrations of total mercury, methylmercury, selenium, and selenium:mercury molar ratios in traditional foods of the Bigstone Cree in Alberta Canada. Chemosphere 250: 126285. https://doi.org/10.1016/j.chemosphere.2020.126285.

Harmens, H., D.A. Norris, G.R. Koerber, A. Buse, E. Steinnes, and A. Rühling. 2008. Temporal trends (1990-2000) in the concentration of cadmium, lead and mercury in mosses across Europe. Environmental Pollution 151: 368-376. https://doi.org/10.1016/ j.envpol.2007.06.043.

Hedegaard, R.V., and J.J. Sloth. 2011. Speciation of arsenic and mercury in feed: Why and how? Biotechnology, Agronomy, Society and Environment 15: 45-51.

HELCOM. 2018. Inputs of hazardous substances to the Baltic Sea. Helsinki, Finland: Baltic Sea Environment.
Hławiczka, S. 2008. Rtęć $w$ środowisku atmosferycznym. Zabrze: Institute of Environmental Engineering Polish Academy of Sciences (in Polish).

Holmes, C.D., D.J. Jacob, and X. Yang. 2006. Global lifetime of elemental mercury against oxidation by atomic bromine in the free troposphere. Geophysical Research Letters 33: L20808. https://doi.org/10.1029/2006GL027176.

Jędruch, A., U. Kwasigroch, M. Bełdowska, and K. Kuliński. 2017. Mercury in suspended matter of the Gulf of Gdańsk: Origin, distribution and transport at the land-sea interface. Marine Pollution Bulletin 118: 354-367. https://doi.org/10.1016/j. marpolbul.2017.03.019.

Jędruch, A., M. Bełdowska, and M. Ziółkowska. 2019. The role of benthic macrofauna in the trophic transfer of mercury in a lowdiversity temperate coastal ecosystem (Puck Lagoon, southern Baltic Sea). Environmental Monitoring and Assessment 191: 137. https://doi.org/10.1007/s10661-019-7257-y.

Kalisińska, E., P. Lisowski, W. Salicki, T. Kucharska, and K. Kavetska. 2009. Mercury in wild terrestrial carnivorous mammals from north-western Poland and unusual fish diet of red fox. Acta Theriologica 54: 345-356. https://doi.org/10.4098/j.at. 0001-7051.032.2008.

Kalisińska, E., H. Budis, N. Lanocha, J. Podlasinska, E. Jedrzejewska, and D.I. Kosik-Bogacka. 2012. Comparison of Hepatic and Nephric Total Mercury Concentrations Between Feral and Ranch American Mink (Neovison vison) from Northwestern Poland. Bulletin of Environmental Contamination and Toxicology 88: 802-806. https://doi.org/10.1007/s00128-012-0555-5.

Kalisińska, E., N. Lanocha-Arendarczyk, D.I. Kosik-Bogacka, H. Budis, B. Pilarczyk, A. Tomza-Marciniak, J. Podlasinska, et al. 2017. Muscle mercury and selenium in fishes and semiaquatic mammals from a selenium-deficient area. Ecotoxicology and Environmental Safety 136: 24-30. https://doi.org/10.1016/j. ecoenv.2016.10.028.

KOBiZE. 2019. Poland's Informative Inventory. Warsaw, Poland: Report. Institute of Environmental Protection-National Research Institute.

Korejwo, E., D. Saniewska, and M. Bełdowska. 2020. Fractionation of mercury in aerosols of the southern Baltic coastal zone. Atmospheric Environment 235: 117623. https://doi.org/10.1016/ j.atmosenv.2020.117623.

Kossakowski, S. 1979. Dynamics of the distribution of mercury in the animal organisms. Polskie Archiwum Weterynaryjne 21: 215-235.

Kowalski, A., and M. Frankowski. 2016. Seasonal variability of mercury concentration in soils, buds and leaves of Acer platanoides and Tilia platyphyllos in central Poland. Environmental Science and Pollution Research 23: 9614-9624. https:// doi.org/10.1007/s11356-016-6179-2.

Kowalski, A., M. Siepak, and L. Boszke. 2007. Mercury contamination of surface and ground waters of Poznan, Poland. Polish Journal of Environmental Studies 16: 67-74.

Kowalski, A., M. Frankowski, A. Zioła-Frankowska, A. MocekPłóciniak, and J. Siepak. 2012. Variability of mercury concentrations in soil and leaves of Acer plantanoides and Tilia platyphyllos in Poznań city, Poland. Soil and Sediment Contamination 21: 1022-1031. https://doi.org/10.1080/15320383.2012. 712074.

Larssen, T., H.A. de Wit, M. Wiker, and K. Halse. 2008. Mercury budget of a small forested boreal catchment in southeast Norway. Science of The Total Environment 404: 290-296. https://doi.org/10.1016/j.scitotenv.2008.03.013.

Lasorsa, B., and S. Allen-Gil. 1995. The Methylmercury to Total Mercury Ratio In Selected Marine, Freshwater, and Terrestrial Organisms. Water, Air, and Soil Pollution 80: 905-913. https:// doi.org/10.1007/bf01189743. 
Lavoie, R.A., T.D. Jardine, M.M. Chumchal, K.A. Kidd, and L.M. Campbell. 2013. Biomagnification of mercury in aquatic food webs: a worldwide meta-analysis. Environmental Science and Technology 47: 13385-13394. https://doi.org/10.1021/ es403103t.

Lech, T., and W. Gubała. 1998. Metale ciężkie w wạtrobie i nerkach saren z regionu województwa krakowskiego. Bromatologia $i$ Chemia Toksykologiczna 31: 287-290 (in Polish).

Lindberg, A., K.A. Björnberg, M. Vahter, and M. Berglund. 2004. Exposure to methylmercury in non-fish-eating people in Sweden. Environmental Research 96: 28-33. https://doi.org/10.1016/j. envres.2003.09.005.

Lindström, M. 2001. Distribution of particulate and reactive mercury in surface waters of Swedish forest lakes - an empirically based predictive model. Ecological Modelling 136: 81-93. https://doi. org/10.1016/s0304-3800(00)00382-3.

Lyytikäinen, M., J. Pätynen, H. Hyvärinen, T. Sipilä, and M. Kunnasranta. 2015. Mercury and Selenium Balance in Endangered Saimaa Ringed Seal Depend on Age and Sex. Environmental Science and Technology 49: 11808-11816. https://doi. org/10.1021/acs.est.5b01555.

Mališová, K., R. Koplík, and O. Mestek. 2015. Speciation of Mercury in Terrestrial Plants Using Vapor Generation and Liquid Chromatography-Inductively Coupled Plasma Mass Spectrometry. Analytical letters 48: 2446-2462. https://doi.org/10.1080/ 00032719.2015 .1039017$.

Maršálek, P., Z. Svobodová, T. Randák, and J. Švehla. 2005. Mercury and Methylmercury Contamination of Fish from the Skalka Reservoir: A Case Study. Acta Veterinaria Brno 74: 427-434. https://doi.org/10.2754/avb200574030427.

Mazurkiewicz, N., and J. Podlasińska. 2014. The mercury content of macrofungi from area of west Pomeranian district. Bromatologia i Chemia Toksykologiczna 47: 114-119.

Miller, A., A. Bignert, P. Porvari, S. Danielsson, and M. Verta. 2013. Mercury in Perch (Perca fluviatilis) from Sweden and Finland. Water, Air, and Soil Pollution 224: 1472. https://doi.org/10. 1007/s11270-013-1472-x.

Musilová, J., P. Trebichalský, I. Jančo, T. Tóth, and M. Šnirc. 2019. Mercury bioaccumulation in Boletus edulis bull. in different forest ecosystems in Slovakia. GeoConference SGEM 19: 753-760. https://doi.org/10.5593/sgem2019/3.2.

Nabrzyski, M. 1975. Mercury, copper, and zinc content in the meat tissue of some freshwater fish. Bromatologia i Chemia Toksykologiczna 8: 313-319.

Nawrocka, A., M. Durkalec, J. Szkoda, A. Filipek, M. Kmiecik, J. Żmudzki, and A. Posyniak. 2020. Total mercury levels in the muscle and liver of livestock and game animals in Poland, 2009-2018. Chemosphere 258: 127311. https://doi.org/10.1016/ j.chemosphere.2020.127311.

Pacyna, E.G., J.M. Pacyna, K. Sundseth, J. Munthe, K. Kindbom, S. Wilson, F. Steenhuisen, and P. Maxson. 2010. Global emission of mercury to the atmosphere from anthropogenic sources in 2005 and projections to 2020. Atmospheric Environment 44: 2487-2499. https://doi.org/10.1016/j.atmosenv.2009.06.009.

Pasieczna, A. 2012. Polish geochemical atlas. Warsaw: Geological Publishing House.

Petersen, G. 1999. Airborne Heavy Metals over Europe: Emissions, Long-Range Transport and Deposition Fluxes to Natural Ecosystems. In Contaminated Forests, ed. I. Linkov and W.R. Schell, 123-132. Dordrecht: Springer.

Pirrone, N., G.J. Keeler, and J.O. Nriagu. 1996. Regional differences in worldwide emissions of mercury to the atmosphere. Atmospheric Environment 30: 2981-2987. https://doi.org/10.1016/ 1352-2310(95)00498-x.

Pirrone, N., S. Cinnirella, X. Feng, R.B. Finkelman, H.R. Friedli, J. Leaner, R. Mason, A.B. Mukherjee, et al. 2010. Global mercury emissions to the atmosphere from anthropogenic and natural sources. Atmospheric Chemistry and Physics 10: 5951-5964. https://doi.org/10.5194/acp-10-5951-2010.

Pogrzeba, M., D. Ciszek, R. Galimska-Stypa, B. Nowak, and A. SasNowosielska. 2016. Ecological strategy for soil contaminated with mercury. Plant and Soil 409: 317-387. https://doi.org/10. 1007/s11104-016-2936-8.

Polak-Juszczak, L. 2017. Methylmercury in fish from the southern Baltic Sea and coastal lagoons as a function of species, size, and region. Toxicology and Industrial Health 33: 1-9. https://doi.org/ $10.1177 / 0748233716685647$.

Polak-Juszczak, L., and T. Nermer. 2016. Methylmercury and Total Mercury in Eels, Anguilla anguilla, from Lakes in Northeastern Poland: Health Risk Assessment. EcoHealth 13: 582-590. https://doi.org/10.1007/s10393-016-1139-3.

Pyta, H., K. Widziewicz-Rzońca, and K. Słaby. 2020. Inhalation exposure to gaseous and particulate bound mercury present in the ambient air over the polluted area of southern Poland. International Journal of Environmental Research and Public Health 17: 4999. https://doi.org/10.3390/ijerph17144999.

Rafaj, P., I. Bertok, J. Cofala, and W. Schöpp. 2013. Scenarios of global mercury emissions from anthropogenic sources. Atmospheric Environment 79: 472-479. https://doi.org/10.1016/j. atmosenv.2013.06.042.

Rieder, S.R., I. Brunner, M. Horvat, A. Jacobs, and B. Frey. 2011. Accumulation of mercury and methylmercury by mushrooms and earthworms from forest soils. Environmental Pollution 159: 2861-2869. https://doi.org/10.1016/j.envpol.2011.04.040.

Saba, M., J. Falandysz, and I.C. Nnorom. 2016. Mercury bioaccumulation by Suillus bovinus mushroom and probable dietary intake with the mushroom meal. Environmental Science and Pollution Research 23: 14549-14559. https://doi.org/10.1007/ s11356-016-6558-8.

Sánchez-Báscones, M., J.M. Antolín-Rodríguez, P. Martín-Ramos, A. González-González, C.T. Bravo-Sánchez, and J. Martín-Gil. 2017. Evolution of mercury content in agricultural soils due to the application of organic and mineral fertilizers. Journal of Soils and Sediments 17: 927-935. https://doi.org/10.1007/ s11368-016-1622-z.

Saniewska, D., M. Bełdowska, J. Bełdowski, and L. Falkowska. 2014a. Mercury in precipitation at an urbanized coastal zone of the Baltic Sea (Poland). Ambio 43: 871-877. https://doi.org/10. 1007/s13280-014-0494-y.

Saniewska, D., M. Bełdowska, J. Bełdowski, M. Saniewski, M. Szubska, A. Romanowski, and L. Falkowska. 2014b. The impact of land use and season on the riverine transport of mercury into the marine coastal zone. Environmental Monitoring and Assessment 186: 7593-7604. https://doi.org/10.1007/s10661-014-3950$\mathrm{z}$.

Saniewska, D., M. Bełdowska, J. Bełdowski, A. Jędruch, M. Saniewski, and L. Falkowska. 2014c. Mercury loads into the sea associated with extreme flood. Environmental Pollution 191: 93-100. https://doi.org/10.1016/j.envpol.2014.04.003.

Saniewska, D., M. Bełdowska, J. Bełdowski, M. Saniewski, K. Gębka, M. Szubska, and A. Wochna. 2018. Impact of intense rains and flooding on mercury riverine input to the coastal zone. Marine Pollution Bulletin 127: 593-602. https://doi.org/10.1016/ j.marpolbul.2017.12.058.

Saniewska, D., K. Gębka, M. Bełdowska, G. Siedlewicz, and J. Bełdowski. 2019. Impact of hydrotechnical works on outflow of mercury from the riparian zone to a river and input to the sea. Marine Pollution Bulletin 142: 361-376. https://doi.org/10.1016/ j.marpolbul.2019.03.059.

Schwesig, D., and O. Krebs. 2003. The role of ground vegetation in the uptake of mercury and methylmercury in a forest ecosystem. 
Plant and Soil 253: 445-455. https://doi.org/10.1023/A: 1024891014028.

Skotak, K., A. Degórska, Z. Prządka, and M. Syrzycki. 2019. Assessment of air pollution with mercury at regional background stations in Poland for 2018. Warsaw, Poland (in Polish): State Environmental Monitoring.

Smith, K.M., P.W. Abrahams, M.P. Dagleish, and J. Steigmajer. 2009. The intake of lead and associated metals by sheep grazing mining-contaminated floodplain pastures in mid-Wales, UK: I. Soil ingestion, soil-metal partitioning and potential availability to pasture herbage and livestock. Science of The Total Environment 407: 3731-3739. https://doi.org/10.1016/j.scitotenv.2009. 02.032 .

Sobańska, M.A. 2005. Wild boar hair (Sus scrofa) as a non-invasive indicator of mercury pollution. Science of The Total Environment 339: 81-88. https://doi.org/10.1016/j.scitotenv.2004.07. 018.

Stamenkovic, J., and M.S. Gustin. 2009. Nonstomatal versus Stomatal Uptake of Atmospheric Mercury. Environmental Science and Technology 43: 1367-1372. https://doi.org/10.1021/es801583a.

Strom, S.M. 2008. Total Mercury and Methylmercury Residues in River Otters (Lutra canadensis) from Wisconsin. Archives of Environmental Contamination and Toxicology 54: 546-554. https://doi.org/10.1007/s00244-007-9053-x.

Szkoda, J., and J. Żmudzki. 2001. Toxic elements in tissues of game animals. Medycyna Weterynaryjna 57: 883-886.

Szkoda, J., M. Durkalec, R. Kolacz, S. Opaliński, and J. Żmudzki. 2012. Content of cadmium, lead and mercury in the tissues of game animals. Medycyna Weterynaryjna 68: 689-692.

Szprengier, T. 1976. Mercury levels in the muscles and kidneys of horses, cows, and pigs. Bulletin of the Veterinary Institute in Pulawy 20: 54-57.

UNEP. 2013. Minamata Convention on mercury. http://www. mercuryconvention.org

UNEP. 2019. Global Mercury Assessment 2018. Geneva, Switzerland: Chemicals and Health Branch.

US EPA. 1992. Water Quality Standards, Establishment of Numeric Criteria for Priority Toxic Pollutants, States Compliance, Final Rule. Fed. Regist. 40 CFR Part 131, 57/246.

Wang, Y., Q. Xie, Q. Xu, J. Xue, C. Zhang, and D. Wang. 2019. Mercury bioaccumulation in fish in an artificial lake used to carry out cage culture. Journal of Environmental Sciences 78: 352-359. https://doi.org/10.1016/j.jes.2018.11.016.

Wängberg, I., J. Munthe, N. Pirrone, A. Iverfeldt, E. Bahlman, P. Costa, R. Ebinghaus, X. Feng, et al. 2001. Atmospheric mercury distribution in northern Europe and in the Mediterranean region. Atmospheric Environment 35: 3019-3025. https://doi.org/10. 1016/S1352-2310(01)00105-4.

Wyrzykowska, B., J. Falandysz, and G. Jarzyńska. 2012. Metals in edible fish from Vistula River and Dead Vistula River channel, Baltic Sea. Journal of Environmental Science and Health, Part B 47: 296-305. https://doi.org/10.1080/03601234.2012.638890.

Yin, R.W., G. Zhang, Z. Sun, J.P. Feng, L. Hurley, L. Shang. Yang, and X. Feng. 2017. Mercury risk in poultry in the Wanshan Mercury Mine, China. Environmental Pollution 230: 810-816. https://doi.org/10.1016/j.envpol.2017.07.027.

Zhang, Y., D.J. Jacob, H.M. Horowitz, L. Chen, H.M. Amos, D.P. Krabbenhoft, F. Slemr, V.L. St, Louis, et al. 2016. Observed decrease in atmospheric mercury explained by global decline in anthropogenic emissions. Proceedings of the National Academy of Sciences USA 113: 526-531. https://doi.org/10.1073/pnas. 1516312113

Publisher's Note Springer Nature remains neutral with regard to jurisdictional claims in published maps and institutional affiliations.

\section{AUTHOR BIOGRAPHIES}

Agnieszka Jędruch is a postdoctoral researcher at the Faculty of Oceanography and Geography of the University of Gdańsk. Her research interests include environmental geochemistry, bioaccumulation and trophic transfer of mercury in aquatic ecosystems.

Address: Faculty of Oceanography and Geography, Institute of Oceanography, Department of Marine Chemistry and Environmental Protection, University of Gdańsk, Al. Marszałka Piłsudskiego 46, 81378 Gdynia, Poland.

e-mail: agnieszka.jedruch@ug.edu.pl

Lucyna Falkowska $(\bowtie)$ is a professor at the Faculty of Oceanography and Geography of the University of Gdańsk. Her research interests include oceanography, marine and atmospheric chemistry, marine ecology, trace metal in biota, and maternal transfer of xenobiotics.

Address: Faculty of Oceanography and Geography, Institute of Oceanography, Department of Marine Chemistry and Environmental Protection, University of Gdańsk, Al. Marszałka Piłsudskiego 46, 81378 Gdynia, Poland.

e-mail: lucyna.falkowska@ug.edu.pl; lucynafalkowska@gmail.com

Dominika Saniewska is an assistant professor at the Faculty of Oceanography and Geography of the University of Gdańsk. Her research interests include oceanography, marine chemistry, marine and terrestrial pollution, aquatic geochemistry and environment protection.

Address: Faculty of Oceanography and Geography, Institute of Oceanography, Department of Marine Chemistry and Environmental Protection, University of Gdańsk, Al. Marszałka Piłsudskiego 46, 81378 Gdynia, Poland.

e-mail: dominika.saniewska@gmail.com

Maciej Durkalec is a researcher at the National Veterinary Research Institute. His research interests include the bioaccumulation of toxic elements, their transfer in terrestrial food webs, adverse effects on wildlife, and the exposure to toxic elements via the consumption of food of animal origin.

Address: Department of Pharmacology and Toxicology, National Veterinary Research Institute, Al. Partyzantów 57, 24-100 Puławy, Poland.

e-mail: maciej.durkalec@piwet.pulawy.pl

Agnieszka Nawrocka is a researcher at the National Veterinary Research Institute. Her research interests include analytical chemistry, food toxicology, instrumental analysis of chemical elements and chemical speciation.

Address: Department of Pharmacology and Toxicology, National Veterinary Research Institute, Al. Partyzantów 57, 24-100 Puławy, Poland.

e-mail: agnieszka.nawrocka@ piwet.pulawy.pl

Elżbieta Kalisińska is a professor at the Faculty of Pharmacy of the Pomeranian Medical University. Her research interests include ecotoxicology, zoology, ecology, and parasitology.

Address: Faculty of Pharmacy, Medical Biotechnology and Laboratory Medicine, Department of Biology and Medical Parasitology, Pomeranian Medical University, Al. Powstańców Wielkopolskich 72, 70-111 Szczecin, Poland.

e-mail: ekalist@pum.edu.pl 
Artur Kowalski is an associate professor at the Faculty of Chemistry of the Adam Mickiewicz University. His research interests include total mercury and mercury fractions in complex matrix samples (soils, sludge, water, bottom sediments, plants), food analytics, and environmental protection.

Address: Faculty of Chemistry, Department of Analytical and Environmental Chemistry, Adam Mickiewicz University, ul. Uniwersytetu Poznańskiego 8, 61-614 Poznań, Poland.

e-mail: artur.kowalski@amu.edu.pl

Józef M. Pacyna is a professor at the Faculty of Energy and Fuels of the AGH University of Science and Technology. His research interests include biogeochemical cycling of nutrients and pollutants in aquatic ecosystems, assessment of emissions sources and emission inventories of various chemicals, assessment of global changes of environmental components in coastal areas caused by anthropogenic drivers, and assessment of functioning and structures of different coastal ecosystems in the future.

Address: Faculty of Energy and Fuels, AGH University of Science and Technology, ul. Mickiewicza 30, 30-059 Kraków, Poland. e-mail: jpacyna@agh.edu.pl 